\title{
THE MACAÉ FORMATION, CAMPOS BASIN, BRAZIL: ITS EVOLUTION IN THE CONTEXT OF THE INITIAL HISTORY OF THE SOUTH ATLANTIC
}

\author{
ADALI RICARDO SPADINI*, FERNANDO ROBERTO ESTEVES**, DIMAS DIAS-BRITO*, \\ RICARDO LATGÉ MILWARD AZEVEDO*, and RENÉ RODRIGUES*
}

\begin{abstract}
The Macae Formation (Albian-Lower Turonian, Campos Basin) is very significant for understanding the early history of the South Atlantic north of the Walvis Ridge/São Paulo Plateau system. Deposition of the unit immediately succeeded the Aptian evaporitic event, and preceeded the oceanic phase that began in post-Early Turonian times. This is probably the best known Middle Cretaceous carbonate record in the South Atlantic. It consists of the Lower Macae (Early to Middle Albian), formed dominantly by limestones deposited mostly in shallow neritic environment, and the Upper Macaé (Late Albian-Early Turonian) with calcilutites overlain by marls and shales, deposited during progressive sea level rise. A tidal flat system was developed in the southern portion of the basin during deposition of the lowermost Macae Formation, with supratidal, intertidal, and lagoonal environments. Burrowed carbonate mudstones were deposited in shallow shef environments, and ooids and peloids in a high energy offshore shoal system. Hypersalinity prevailled during that time, as suggested by the low biotic diversity and the carbon isotope values. Very negative oxygen isotope values indicate that surface water temperatures were high. Oncolite limestones and subordinate calcilutites prevail in the middle and upper parts of the Lower Macae, chiefly deposited in shallow neritic environment. Hypersalinity and high water temperature persisted, as indicated by paleoecological and isotopic studies. The Macae sea was then a juvenile ecosystem, unstable and poor in nutrients, with maximum depth values around $50 \mathrm{~m}$. The Upper Macaé carbonate mudstones, Late Albian in age, are rich in calcispherulids. Its abundant pelagic biota probably reflects desalinization and increase in nutrients of surface waters related to the South Atlantic expansion and consequent increase in water volume and circulation. The benthic foraminifera are suggestive of deep neritic environments $(100-200 \mathrm{~m})$. "At the end of the latest Albian, a rhythmic deposition of calcilutites and marls was probably caused by climatic variations (dry/warm to warm/wet climate cycles). From the Cenomanian to the Turonian, already under a warm/wet climate, were deposited the fine-grained siliciclastics, mostly in upper bathyal environment; episodic anoxic conditions are represented by laminated black shales, frequently rich in radiolaria, and with a relatively high organic carbon content".
\end{abstract}

RESUMO A FORMAÇÃO MACAÉ, BACIA DE CAMPOS, BRASIL: SUA EVOLUÇÃO NO CONTEXTO DA HISTÓRIA INICIAL DO ATLÂNTICO SUL. A Formação Macaé (Albiano-Eoturoniano, Bacia de Campos) é muito significativa para o entendimento da história inicial do Atlântico Sul ao norte do sistema Walvis Ridge-Platô de São Paulo. Sua deposição sucedeu imediatamente ao evento evaporítico aptiano e precedeu a fase oceânica, que começou em tempos pós-eoturonianos. Ela é, provavelmente, o registro carbonático mesocretácico mais bem conhecido em todo o Atlântico Sul. É composta pelo Macaé Inferior (Eo- a Mesoalbiano), constituído dominantemente de calcários, depositados sobretudo em meio nerítico raso, e pelo Macaé Superior (Neoalbiano-Eoturoniano), com calcilutitos sobrepostos por margas e folhelhos, acumulados em resposta a eventos transgressivos. Durante a deposiçăo da parte mais inferior da Formação Macaé, um sistema de planícies de maré se desenvolveu a sul da bacia, com ambientes de supramaré, intermaré e lagunas. Calcilutitos bioturbados preencheram áreas calmas de ambiente nerítico raso enquanto oóides e pelóides se acumularam em sistemas de bancos de alta energia desenvolvidos em áreas distais. A baixa diversidade biótica e os valores de isótopos de carbono sugerem que, naquele tempo, o corpo marinho era hipersalino. Valores muito negativos de isótopos de oxigênio indicam que as temperaturas das águas superficiais eram altas. Calcários oncolíticos, sobretudo, e calcilutitos predominam nas partes média e superior do Macaé Inferior, tendo sido depositados em ambiente nerítico raso. O corpo d'água continuava hipersalino e quente, como sugerem os estudos paleoecológicos e isotópicos. O Mar Macá́ era então um ecossistema juvenil, instável e pobre em nutrientes, com profundidades máximas em torno de $50 \mathrm{~m}$. As rochas carbonáticas do Macaé Superior consistem em calcilutitos ricos em calcisferulídeos. Sua abundante biota pelágica provavelmente reflete a dessalinização e o incremento de nutrientes nas águas superficiais do corpo marinho resultantes de importante expansão do Atlântico Sul ocorrida no Neoalbiano. Uma melhor circulação de águas passou a ocorrer na bacia, cuja batimetria média oscilava entre 100 e $200 \mathrm{~m}$. "Ao final do Albiano terminal ocorreu uma deposição rítmica de calcilutitos e margas, causada, provavelmente, por variaçōes climáticas alternantes (ciclos quente/seco e quente/úmido). A partir do Cenomaniano, já sob clima quente e úmido, foram acumulados sedimentos siliciclásticos finos, em ambientes batial superior (200-500 m); condiçōes episódicas de anoxia ocorreram neste intervalo de tempo, o que $\varepsilon$ atestado pela presença de folhelhos negros, laminados, näo bioturbados, frequentemente ricos em radiolários, e relativamente ricos emcarbonoorgânico"'.

INTRODUCTION The Albian carbonate sequences of the eastern Brazilian margin contain the first typical records of the South Atlantic Ocean. Among all these carbonate sequences, the Macaé Formation of the Campos Basin is the one that presents of greatest number of data, recovered from more than 300 wells, which provide valuable information for the understanding of the South Atlantic evolution. The Macaé Formation is economically important, as it produces hydrocarbons from structural-stratigraphic traps in six oil fields.

The main purpose of this work is to characterize the depositional history of the Macaé Formation in order to contribute to the global understanding of the initial context of the South Atlantic. The investigation was based on sedimentological, biostratigraphic, paleoecological, and geochemical data. The results summarizes the effort of many

* Centro de Pesquisas e Desenvolvimento da Petrobrás (Cenpes), Cidade Universitária, Ilha do Fundão, quadra 07, CEP 21910, Rio de Janeiro, RJ, Brasil

** Departamento de Exploraçåo da Petrobrás (Depex), Av. Chile, 65, 13ㅇandar, CEP 20031, Rio de Janeiro, RJ, Brasil 
people in Petrobrás since the beginning of exploration in the Campos Basin.

Previous detailed facies analysis of the Macae carbonates have been documented by several authors, following the pioneer discovery of Garoupa Field in 1974, the first oil field in the Campos Basin. Tessari \& Tibana (1975) defined the general facies framework, establishing a generic depositional evolution. Carozzi et al. (1977) defined a diageneticdepositional model for the Macae Formation. Falkenhein (1981) concentrated on the general tecto-sedimentary setting, the identification of microfacies and environmental interpretation. Beltrami (1982), using wells and seismic data, established a regional distribution of the carbonate high energy facies along NE-SW structural trend. The siliciclastic section was studied by Guardado et al. (1983). Esteves et al. (1987) proposed a general sedimentary evolution model for the Lower Macaé. Guardado \& Spadini (1987) established a depositional model relating previous rift structures and salt tectonics with the facies distribution. Detailed reservoir studies were performed by several authors (Franke 1981, Baumgarten et al. 1982, Spadini \& Paumer 1983, Baumgarten et al. 1984, Paumer 1984, Scuta 1984, Franz 1987).

Strong efforts in the biostratigraphic research have been made in the Campos Basin since the first oil discovery in the Macaé carbonate reservoirs (Gomide 1976, Uesugui 1976, Dias-Brito 1982, Gomide 1982, Dias-Brito 1985a, Moura \& Praça 1985, Azevedo et al. 1987a, Shimabukuro et al. 1985, Richter 1985, 1987, Shimabukuro 1988, Moura 1988, Antunes 1988). Gomide (1982), based on calcareous nanoplankton, defined an Albian/Cenomanian age for the entire Macaé sequence, recognizing only one biozone (Nannoconus truitti). Uesugui (op. cit.), based on palynomorphs, established a sequence of three informal biounits: the alfa interval defined as probably Early Albian in age; the beta interval defined as Middle Albian in age; and the gamma interval as Late Albian/Cenomanian in age. Dias-Brito (1985a), studying calcispherulids of the fine-grained limestones, defined two informal biozones: the Pithonella sphaerica and the Pithonella sphaerica/Pithonella ovalis/Bonetocardiella conoidea zones. Dias-Brito compared the distribution of the calcispherulids in the Campos Basin and those of the Leg 40, site 363, located in the Angola Basin (Bolli 1978), and considered the alfa zone as Early to Middle Albian in age, and the beta zone as Late Albian. In a recent paper where the biostratigraphy of the basin is summarized, Azevedo et al. (op. cit.), using planktonic foraminifera, calcareous nannofossils and palynomorphs, considered the gamma interval as Late Cenomanian to Early Turonian in age.

A series of paleoecological interpretations of the Macaé carbonates has been made in this decade. The first paleoecological work was performed by Dias-Brito (1982), studying microfossils in thin-section. Following this work, new contributions were given by several authors (Koutsoukos 1984, Dias-Brito \& Azevedo 1986, Azevedo et al. 1987b, Dias-Brito 1987, Koutsoukos 1987, Viviers \& Azevedo, 1988). Environmental interpretations based on carbon and oxygen isotope studies was made by Takaki \& Rodrigues (1984).

\section{STRATIGRAPHIC AND STRUCTURAL FRAME-} WORK The Campos Basin (Fig. 1) is a typical continental margin basin of the Atlantic type. The basin has a minor emergent area, and extends offshore to water dephts greater than $3,000 \mathrm{~m}$, covering an area of $100,000 \mathrm{~km}^{2}$. The Campos Basin was originated during the breaking of the Gondwana supercontinent. The initial rifting occurred during the Rio da Serra Stage, a Brazilian local unit of the Lower Cretaceous (Asmus 1975, Asmus \& Porto 1980).

The stratigraphy of the Campos Basin was first established

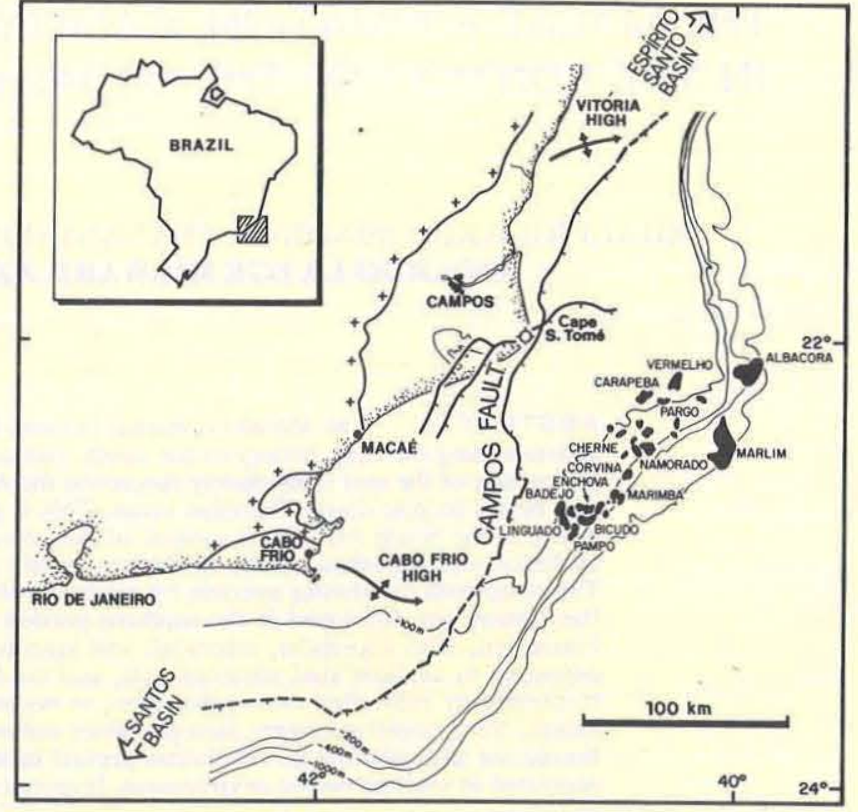

Figure 1-Location map of the Campos Basin

by Schaller (1973). It comprises alluvial-lacustrine sediments of the rift phase, the evaporites of the transitional phase, and carbonates and siliciclastics of the pre-oceanic and oceanic phases (Fig. 2). The Macaé Formation, Albian to Early Turonian in age, characterizes the deposition during the pre-oceanic phase (Fig. 3), overlying the evaporites of the Lagoa Feia Formation. The relationship between the biochronostratigraphic and lithostratigraphic units of the Macaé Formation is showed in the figure 4.

The Macaé Formation is informally divided into Lower and Upper Macaé (Fig. 5). The former, Lower/Middle Albian, was deposited mostly in shallow neritic environment. The lowermost section of the Lower Macaé is characterized by dolomites, overlying in sharp contact the Lagoa Feia nodular anhydrite. The Upper Macaé, Late Albian to Early Turonian in age, is composed of calcilutites and marls, deposited as a result of a transgression over the former shallow platform.

The Macaé Formation is wedge-shaped, pinching out westward against the fault that limits the Lower Cretaceous basin (Fig. 6). During all the Macaé time, siliciclastic facies occur on the coastal portions of the basin.

Two principal structural elements are present in the Campos Basin: the high-angle normal faults of the rift phase, and the adiastrophic structures, mostly normal listric faults, that affected the post-salt sediments. The rift phase is represented by horsts and grabens involving both basement and pre-salt sediments. The adiastrophic structures was formed due to basin tilting and differential compactation (Figueiredo et al. 1983). Salt movement resulted in the formation of pillows which controlled the distribution of Albian shallow water carbonate facies and the thickness of the lowermost section of the Lower Macaé. With the continuing evolution of the salt structure, syndepositional listric faults were generated, developing structures of rollover type (Figueiredo et al. op. cit.), that caused abrupt lateral facies changes at the top of the Lower Macaé.

THE LOWER MACAÉ SEDIMENTATION AND PALEOECOLOGY The Lower Macaé sequence is composed of two distinct sections: the basal one, just above the evaporites, is characterized by strong dolomitization; the upper one, corresponding approximately to the middle and 


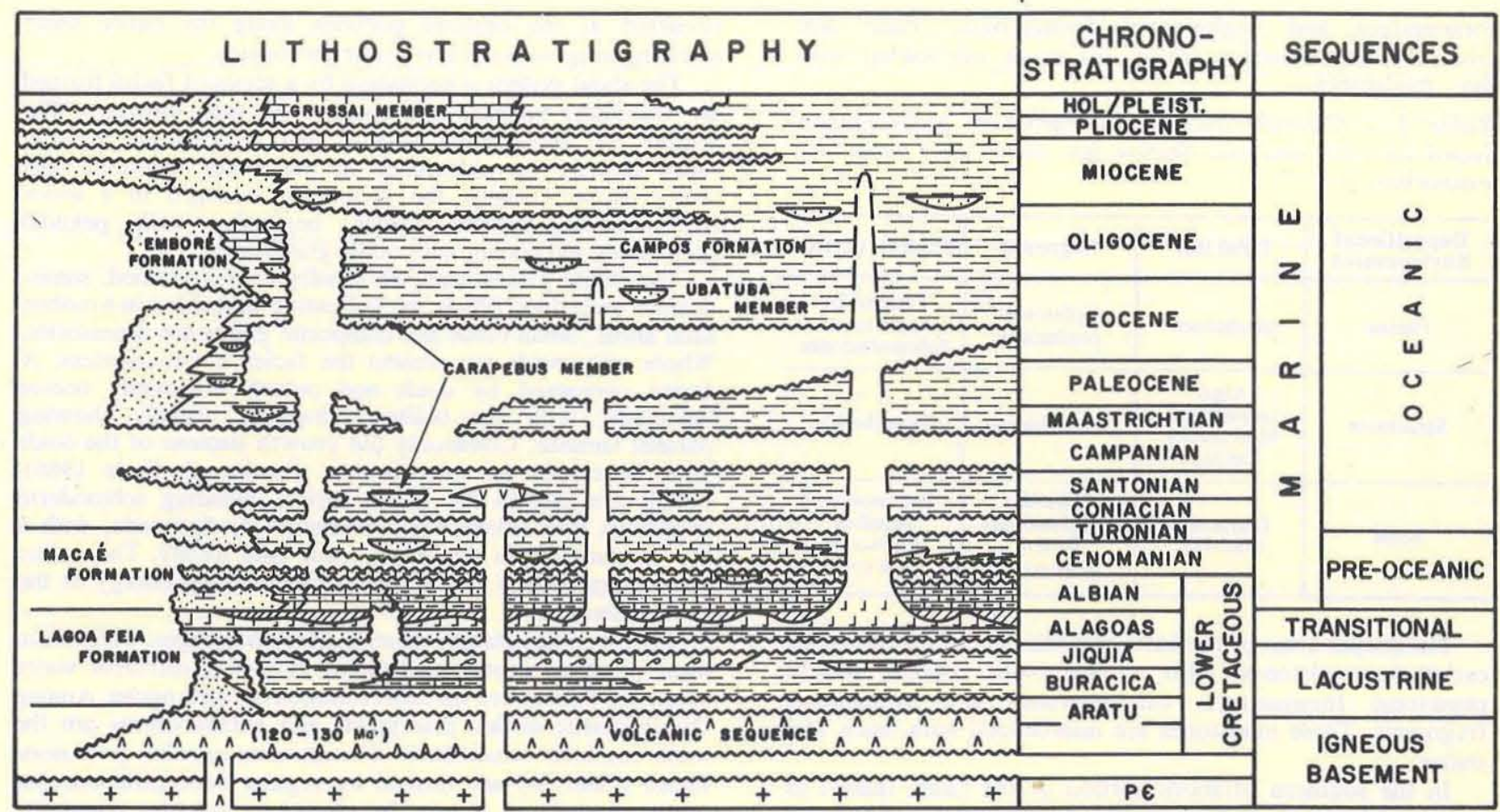

Figure 2 - Stratigraphy of the Campos Basin (after Petrobrás/Depex/Secamp/Sebipe) and related depositional sequences (modified from Dias-Brito \& Azevedo 1986)

upper portions of the sequence, is characterized by the predominance of algal grains (oncolites). Each section can be related to a particular depositional model.

The basal section The change of environmental conditions from the previous evaporitic setting led to the installation of the Macaé carbonate system. A series of environments occur within a carbonate ramp (Fig. 7).

A tidal flat system developed in the southern portion of the basin. This system includes the supratidal, intertidal, and lagoonal environments as defined by Shinn (1983), exhibiting typical facies assemblages and vertical sequences (Fig. 8). The intertidal/supratidal belt is characterized by laminated mudstones, probably of algal origin (Plate 1b). Teepee structures and mudcracks are indicative of subaerial exposure (Plate 1a). Brecciacion associated with collapse is a common feature, usually showing calcite drusy cement. The fossil content is very poor, mostly ostracods and rare miliolids. Thin beds of oolite grainstones probably records deposition by storms. Periods of siliciclastic influx are represented by ripple-laminated, fine-grained arkosic sandștones.

The lagoonal environment that occurs associated with the tidal flat belt is represented by bioturbated pelletoidal mudstones, with a poor biotic content, including miliolids, agglutinated foraminifera, pelecypods and ostracods (Plate 2a and $2 \mathrm{~b}$ ). The occurrence of restricted lagoonal facies suggests the presence of a barrier seaward of the subtidal lagoonal sediments, probably barrier islands, associated with tidal deltas, composed by oolite grainstones, analogous to the modern Trucial Coast, Persian Gulf (Loreau \& Purser 1973).

Open shallow shelf environment is represented by bioturbated pelletoidal mudstones with echinoderms, small
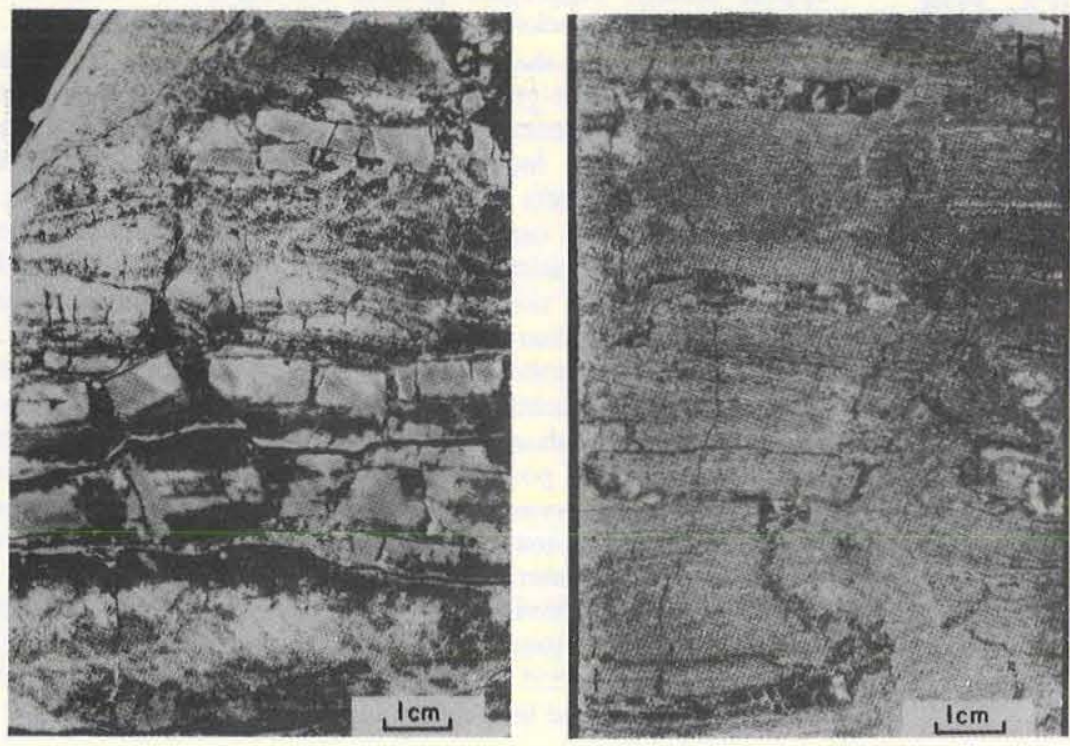

Plate 1 - Tidal flat Macaé facies, deposited just above the Lagoa Feia evaporites: a. teepee structures, characterizing subaerial exposure; b. algal lamination in carbonate mudstones. Brecciacion and collapse developed locally 
foraminifera and agglutinated foraminifera (Plate 2c). Graded dolograinstones (Plate 2d) occur intebedded with the mudstones.

Table 1 - Characteristics of the carbonate sedimentation, based on core analysis. Section just above the Lagoa Feia evaporites

\begin{tabular}{c|c|c|c}
\hline $\begin{array}{c}\text { Depositional } \\
\text { Environment }\end{array}$ & Tidal flat & Lagoonal & Shallow neritic \\
\hline Facies & Mudstones & $\begin{array}{c}\text { Pelletoidal } \\
\text { mudstones }\end{array}$ & $\begin{array}{c}\text { Pelletoidal } \\
\text { mudstones } \\
\text { dolograinstones }\end{array}$ \\
\hline Structures & $\begin{array}{c}\text { Algal } \\
\text { laminations } \\
\text { Mud cracks } \\
\text { Teepees }\end{array}$ & Bioturbation & Bioturbation \\
\hline Biota & $\begin{array}{c}\text { Ostracods } \\
\text { Miliolids }\end{array}$ & $\begin{array}{c}\text { Miliolids } \\
\text { Agglutinated } \\
\text { foram. } \\
\text { pelecypods }\end{array}$ & $\begin{array}{c}\text { Enchinoderms } \\
\text { Rotalids } \\
\text { Ostracods } \\
\text { Pelecypods }\end{array}$ \\
\hline
\end{tabular}

The deeper areas of the basin were the site of deposition of carbonate mudstones, with a poor biotic content, mostly planktonic foraminifera, calcispherulids and echinoderm fragments. These mudstones are interbedded with marls and shales.

In the southern offshore portion of the basin, related to structural highs, were deposited facies composed by ooids and peloids, in a high energy shoal system. These facies were almost completely dolomitized, difficulting the recognition of the depositional texture.

In the northern portion of the basin, the marine carbonates grade westward to siliciclastic facies, mostly fan-delta sandstones and conglomerates and shelf sandstones (Guardado et al. 1983). Interbedded carbonate banks are composed by ooids, pelecypods, and rare red algae. Mixed facies were formed in response to storm and tidal processes (Fig. 9).

The general depositional model of the Lower Macaé correlates with a carbonate, ramp, mostly in shallow neritic environment (Fig. 7).

The scarcity of biotic content is indicative that restrictive conditions prevailed during the deposition of this sequence, probably related to physical and chemical properties. This is true even for the environments out of the embayments and lagoons. The light color, of shallow neritic carbonates, associated with common bioturbation indicates that hypersalinity was the restrictive factor of the environment. The carbon isotope values between 3,0 and $4,0 \%$ PDB standard (Fig. 10) are higher than that of a normal marine water and are also indicative of hypersalinity. The presence of evaporites just below the sequence also led to this interpretation. High water surface temperature is suggested by the oxygen isotope values around $5,0 \%$ PDB standard and by the predominance of oolitic and peloidal grains, which nowadays are observed only in tropical settings (Leonard et al. 1981).

The upper section The lithofacies of this part of the Lower Macaé were deposited on a carbonate ramp, in three depositional environments (Fig. 11): a. high energy shoal system, eveloped in the southern positive areas and in the NE shallow banks trend; b. shelf enviromnent used here as defined by Wilson (1975) as an area on top of a ramp or platform, including a shallow portion adjacent to the shallow bank (few tens of meters) and the deeper offshore areas, implying in tens of meters, even a hundred meters deep."; c. basinal enviromnent corresponding to the deep-water areas, synonymous with "outermost ramp" (Budd \& Loucks 1981). Each one of the enviromnent is characterized by distinct facies assemblages and vertical sequences. Siliciclastic rocks occurred at the onshore portions along the entire basin interfingering with shallow water carbonates.

The shoal system is composed by a series of facies formed by oncolites, peloids, and ooids, with rare bioclasts. The variety of depositional texture and composition reflects more directly the difference in the water agitation than water depht. Usually, the facies are arranged in a series of shallowing-upward cycles, beginning with peloidal packstones and ending with oolite grainstones.

The oolite grainstones are usually coarse-grained, sometimes crossbedded (Plate 3a), indicating deposition in a mobile sand shoal. Small ooids and composite grains are accessories. Where only ooids are present the facies is structureless. A facies composed by ooids and peloids commonly occurs associated with the oolite grainstones, usually showing parallel laminae. Commonly the growth laminae of the ooids were destroyed by micritization (Spadini \& Faria 1986). Fossils are rare in the oolitic facies, including echinoderm fragments and pelecypods. Submarine hardgrounds, with a few centimeters in thickness, occur only locally. The oolitic facies corresponds to the highest depositional energy of the shoal system.

The oncolites display several sizes and shapes. They form three principal depositional facies, reflecting different water agitation. Peloids are the most common oncolite nuclei. Among the bioclastic nuclei, pelecypods and enchinoderms are the most common constituents. Structureless oncolite grainstone facies (Plate $3 \mathrm{~b}$ ) are formed by regular concentric oncolite grains, usually 2-3 $\mathrm{mm}$ in diameter. Peloids, composite grains, and ooids are also present. Bioclasts are rare $(1-2 \%)$, including agglutinate foraminifera, textulariids, miliodis, mollusks and echinoderms. Peloidal/oncolite grainstones are normally associated with the oncolite grainstones; this facies is massive, sometimes burrowed, locally with parallel or inclined laminae. The oncolite packstones are composed by oncolites 2-5 $\mathrm{mm}$ in diameter (Plate 3c), many of them displaying irregular growth bands. Oncolites up to $1 \mathrm{~cm}$ occur locally. This facies is massive to burrowed and shows a variable percentage of peloids and microoncolites. Bioclasts are rare, including textularids, gastropods, pelecypods, echinoderms, miliolids, and hyaline foraminifera.

The peloidal grainstones are commonly burrowed, with a low percentage of ooids and oncolites. Bioclasts (up to 5\%) include mostly echinoderm fragments, some textularids, and milioids, and very rare planktonic foraminifera. Peloidal packstones have a higher percentage of bioclasts, principally echinoderms (echinoids) and pelecypods. Other bioclasts, including textularids, agglutinate foraminifera, and miliolids, are less important. Gastropods and planktonic foraminifera appear locally. Aggregate grains, oncolites, and ooids are accessories in the packstones.

The low energy shelf environment is characterized by the deposition of fine-grained limestones. These facies are mottled to wispy-laminated, with up to $5 \%$ of bioclasts (Plate $3 d$ ). The bioclasts include mostly foraminifera and small echinoderm fragments (possible related to pelagic species?). Micromollusks and ostracods are rare. The rare planktonic foraminifera are basically represented by hedbergellids and favisellids, while the scarse small benthic foraminifera comprises Lenticulina spp., nodosarids, Trocholina spp.; textularids and miliolids are very rare. Calcispherulidae are also rare, locally reaching up to $5 \%$, represented mostly by the specie Pithonella sphaerica; Pithonella ovalis is scattered, and rare. In the inner portions of the shelf the matrix of the fine-grained limestones is peloidal (calcisiltite). In the outer shelf homogeneous matrix is common, but the biota is similar to that one of the inner portion.

The basinal environment is also characterized by fine-grained limestones, but with a greater ammount of planktonic forams and calcispherulids. Shales and marls occur interbedded with the limestones. 


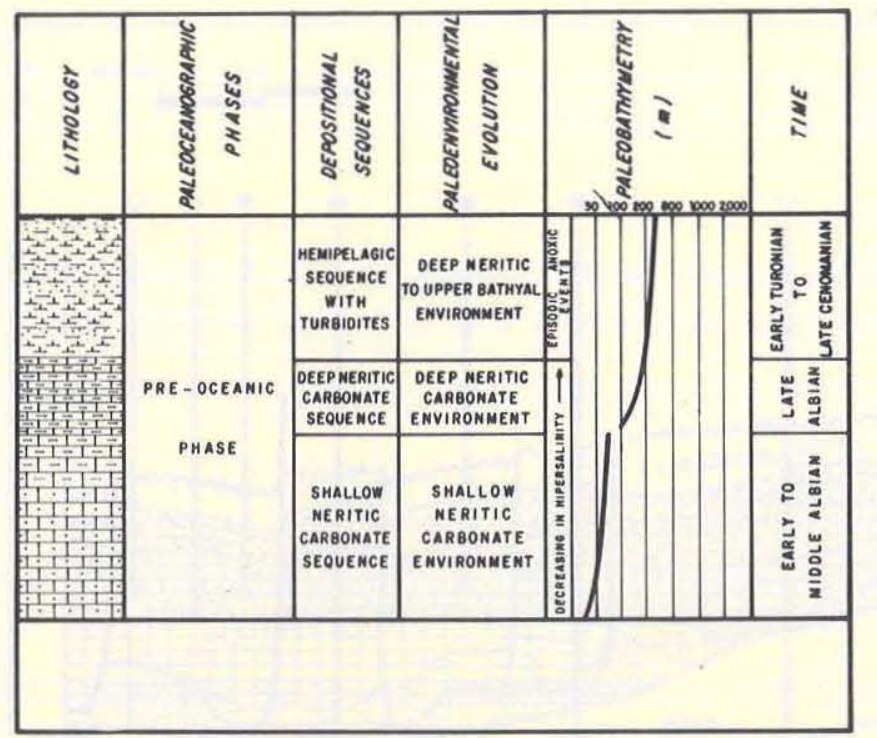

Figure 3 - Diagramatic chart showing the evolution of the Macaé sedimentation in the central area of the Campos Basin (from Dias-Brito \& Azevedo 1986)

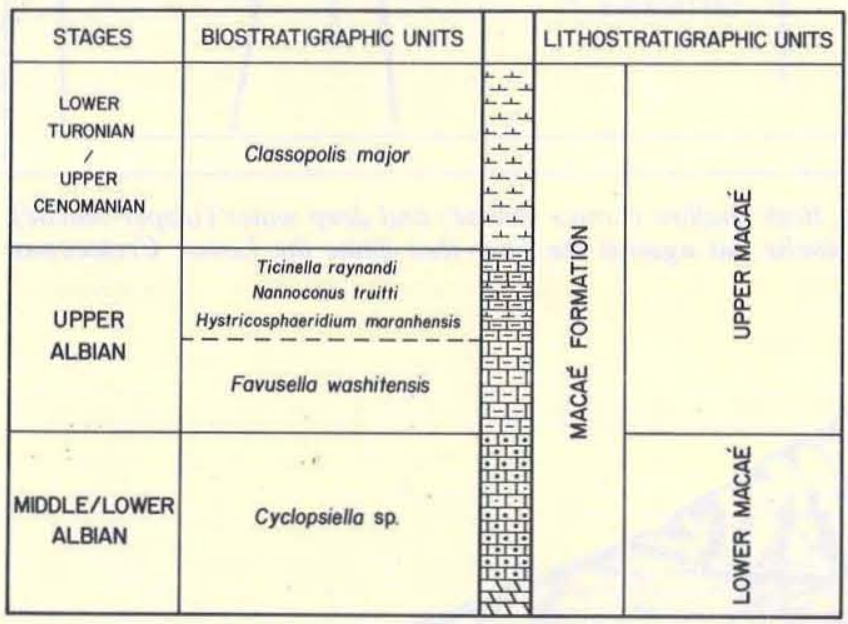

Figure 4-Chart showing the correlation among the litho-, bio- and chronostratigraphic units of the Macaé Formation

The carbonate deposits grade westward to siliciclastic facies along all the basin (Fig. 12). In the northern area, the terrigenous influx is much stronger, causing a NE shifting of the carbonate belt.

At the end of the Lower Macaé, the bathymetric difference between the shallow shelf and the deeper parts of the basin was enlarged. It is believed that the maximum paleobathimetry in the present explorated areas could have not exceeded $200 \mathrm{~m}$ (Fig. 13), as evidenced by paleoecological studies (Azevedo et al. 1987).

The paleo-oceanographic conditions practically remained unchanged when compared with that of the basal Macaé. The general restrictive conditions still persisted. It is evidenced from the scarcity and low diversity of the biota, as indicated by the several studies on the Macaé carbonates, already cited. The light color of the carbonates, presence of bioturbation and the low content in organic-carbon, indicating a well-oxygenated bottom, led to the conclusion that the hypersalinity was the chemical restrictive factor (Dias-Brito 1982). The carbon isotope values around $4,0 \%$ PDB standards (Fig. 14) support this interpretation about the hypersalinity. On the other hand, this carbon isotope values slightly more positive than that of the lower section (Fig. 10) could indicate an increase in oceanic photosynthetic activity, probably related to the oncolite (cyanobacteria) bloom. Bloom of

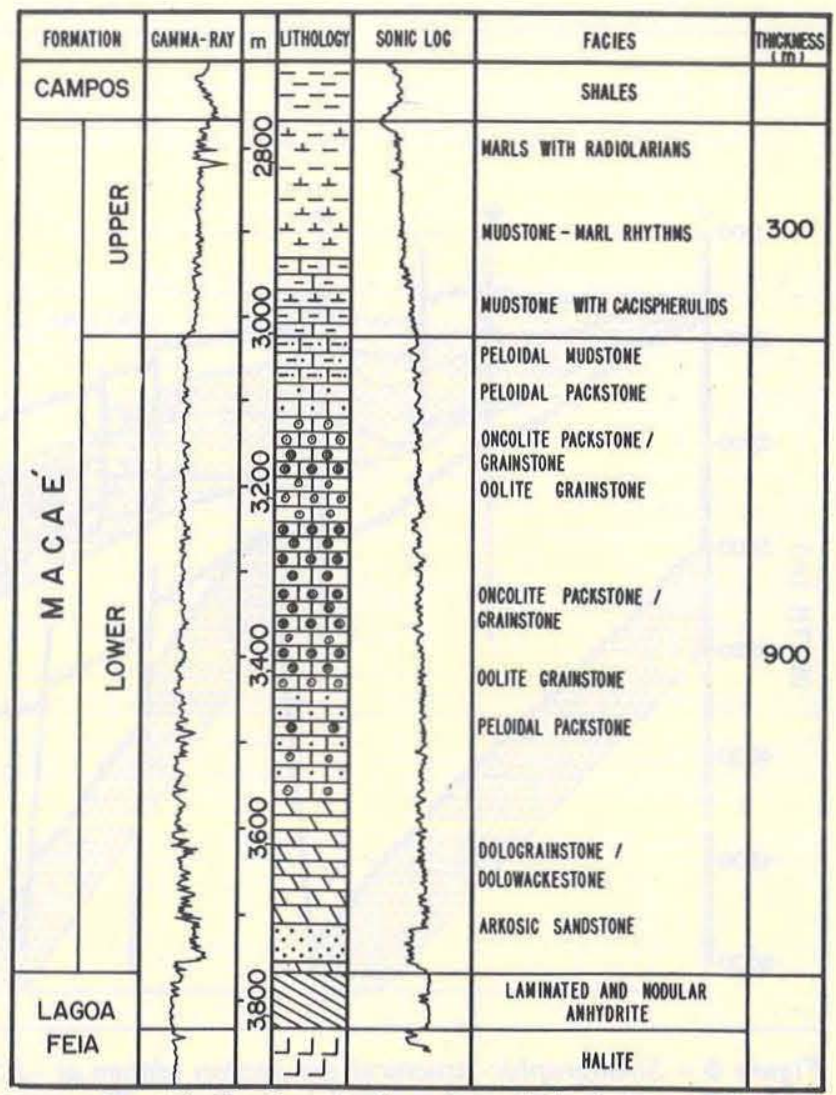

Figure 5 -Idealized vertical section of the Lower and Upper Macaé. The thickness corresponds to maximum values at the central portion of the basin

oportunistic species such as Pithonella sphaerica (now considered a calcareous dinoflagellate, Hulterberg 1985, Keupp 1987), that occurs in the Macaé fine-grained limestones, also contributed to the increase of the photosynthetic activity in the Macaé Sea, compared with the immediately preceding phase. This fact is clearly observed in the Cretaceous Potiguar Basin, northeastern Brazil, in similar paleoceanographic conditions (Dias-Brito 1985b). The surface water temperature still high, as evidenced by the presence of planktonic foraminifera with characteristics that are related to the subtropical-tropical belts, like the Favusella washitensis; it is also suggested by the occurrence of the calcareous nannoplankton Nannoconus truitti, which shows clear relationships with Tethyan forms (Wiedmann \& Neugebauer 1978, apud Dias-Brito op. cit.). A slight lowering in the surface water temperature is indicated by oxygen isotope values gradually less negative (Fig. 14). During the entire Lower Macaé deposition, the basin, partly closed by shallow sills, and under hot and dry climate, was submitted to a negative water balance, the evaporation greater than precipitation and runoff (Dias-Brito 1982).

THE UPPER MACAÉ SEDIMENTATION AND PALEOECOLOGY This section is informally divided into three intervals (Spadini 1982, Spadini et al. 1987). The basal one is composed by mudstones showing a significative enrichment in the planktonic content, mainly calcispherulids. The intermediate section is characterized by rhythmic limestones-marls. The upper section is composed by marls rich in radiolarians.

The basal interval is formed by dense mudstones, usually developing wispy laminations; the laminae are usually less than $5 \mathrm{~cm}$ thick, and are characterized by the high clay content. This interval is characterized by the significative presence of planktonic forms (Plate 4). Calcispherulids are dominant, including the species Phitonella sphaerica, 


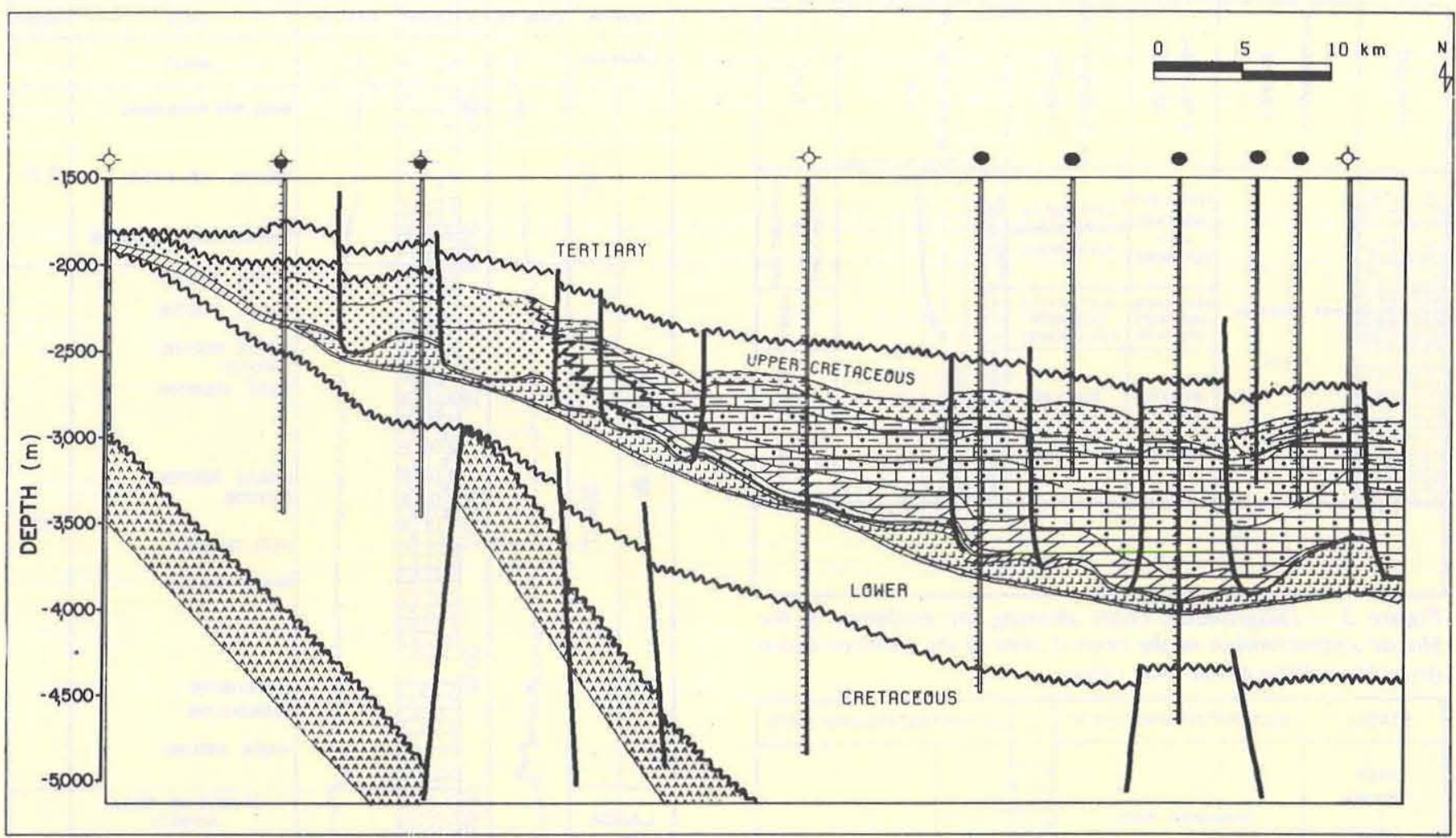

Figure 6 - Stratigraphic-structural dip section (datum at -1,500 m). Both shallow (Lower Macaé) and deep water (Upper Macaé) carbonates grade westward to siliciclastic facies. The entire unit pinchs out against the fault that limits the Lower Cretaceous sequence

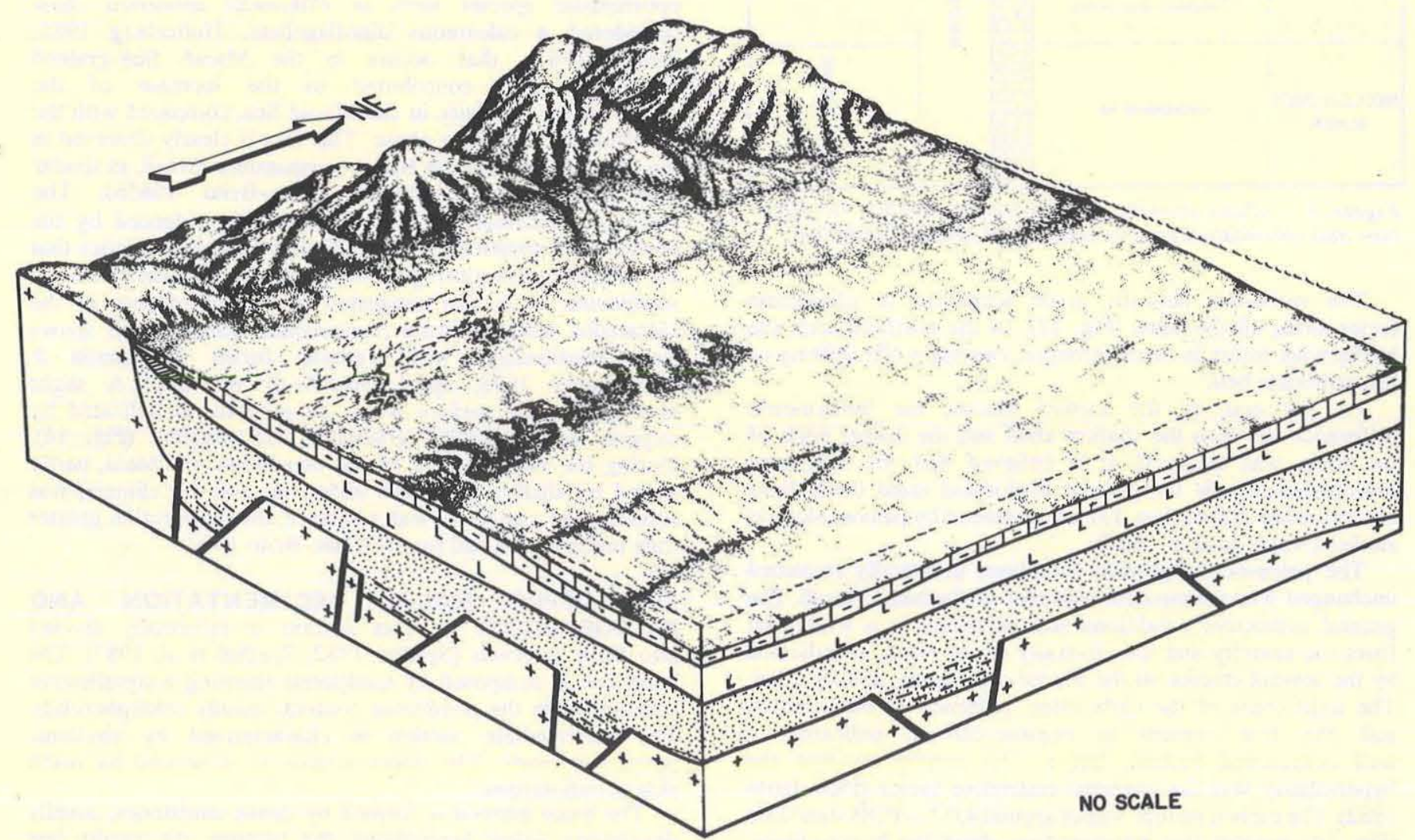

Figure 7 -Depositional model for the lowermost portion of the Lower Macaé. Legend: see figure 11 

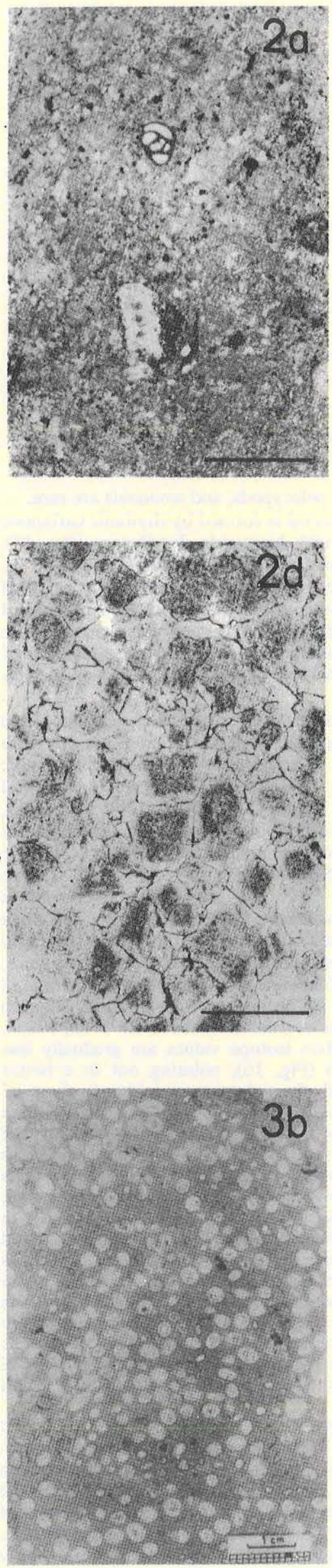

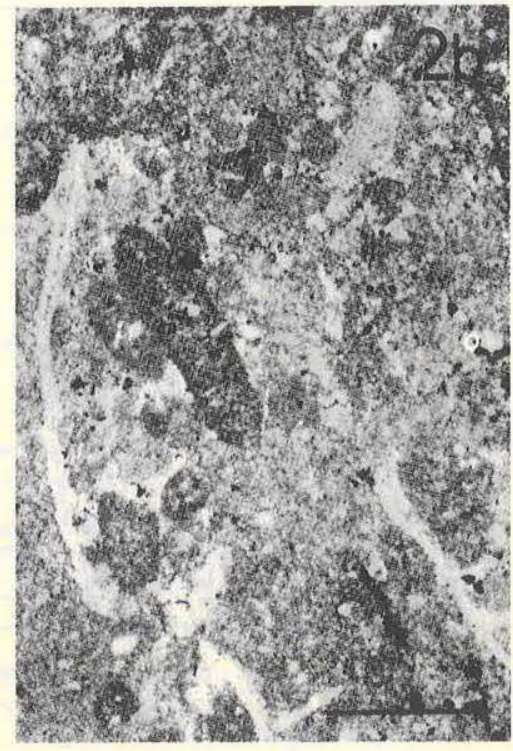

Plate 2-Carbonate facies photomicrographs of the basal section, Lower Macaé: a. lagoonal facies. Micritic/pelletoidal mudstone with miliolids (center) and pelecypod fragments. Scattered quartz grains; b. pelletoidal lagoonal sediment, with pelecypod fragments; c. shelf facies. Mudstone with rare echinoderms (center) and small Foraminifera; d. cloudy center-clear rim anhedral to euhedral dolomite crystals. Scale bar equal to $0.5 \mathrm{~mm}$

Plate 3-Facies of the uppermost section of the Lower Macaé: a. crossbedded oolite grainstone; b. structureless oncolite grainstone; c. photomicrograph of large oncolite grains. Scale bar equal $1 \mathrm{~mm}$; d. photomicrograph of shelf mudstones. Echinoderm fragments (E) and small foraminifera (arrow) are the most common fossils. Scale bar equal $0.2 \mathrm{~mm}$

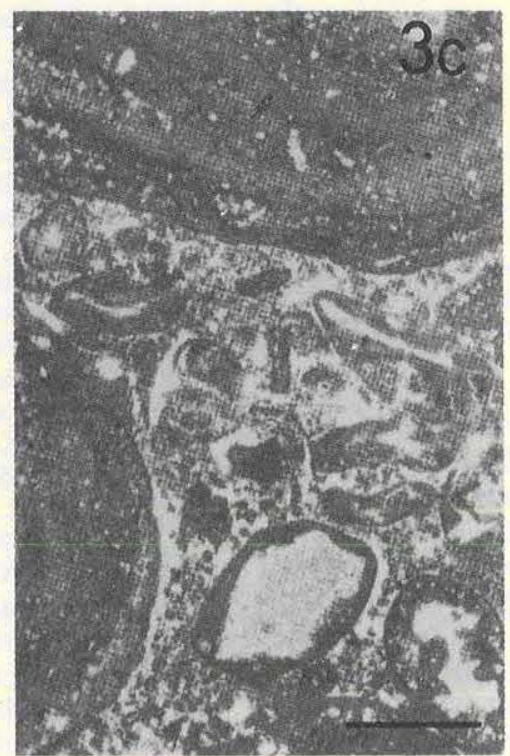

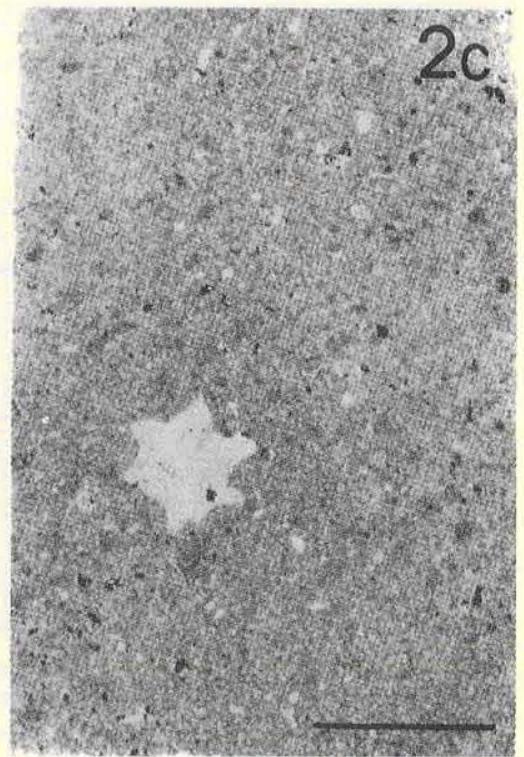
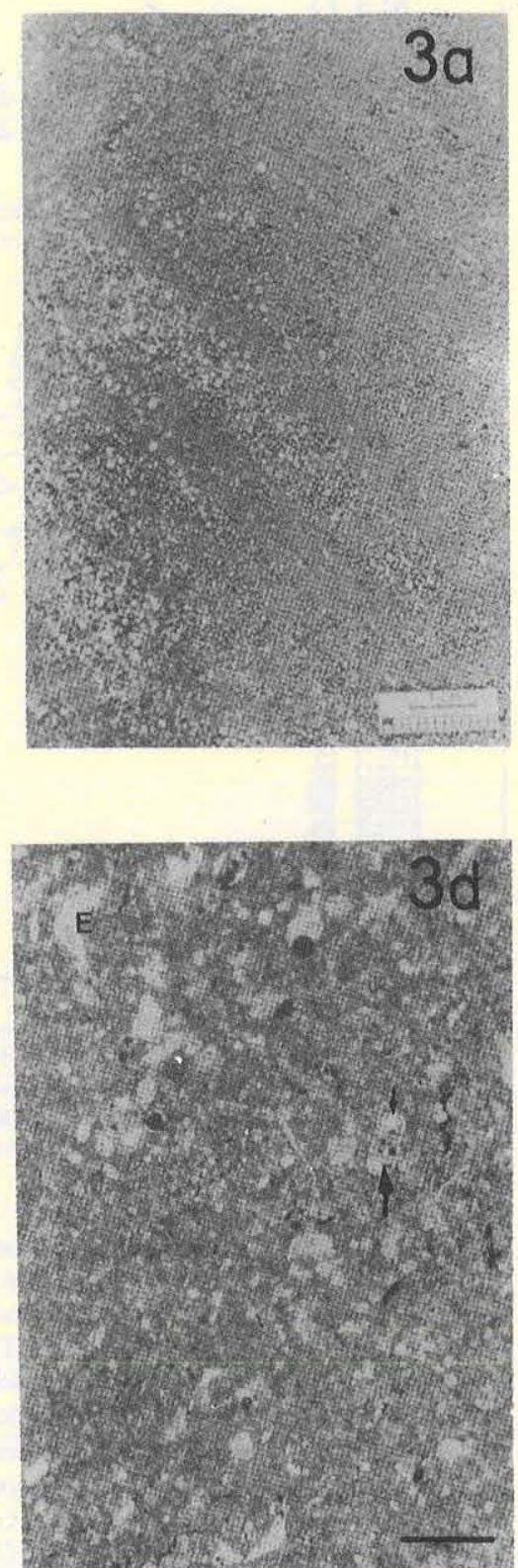


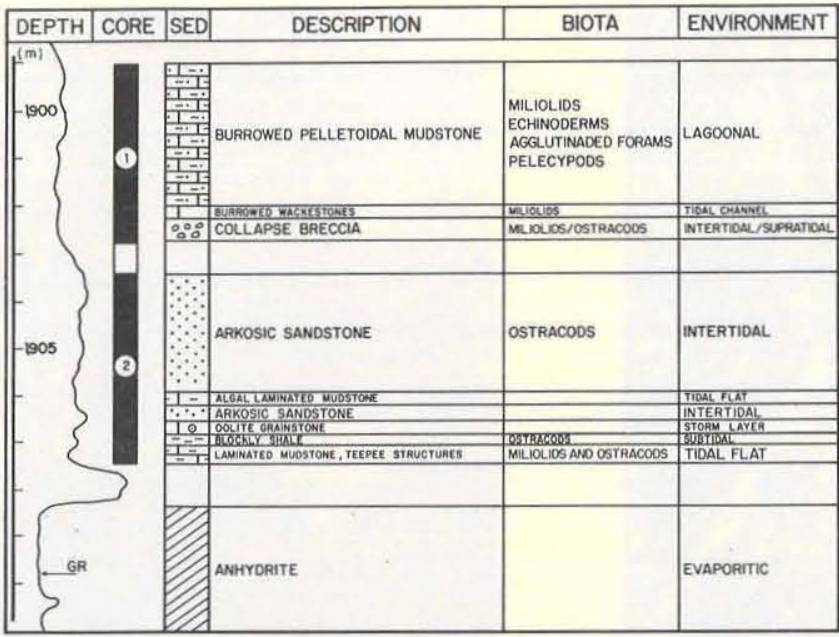

Figure 8 - Vertical core sequence of supratidal to subtidal facies, deposited just above the Lagoa Feia evaporites

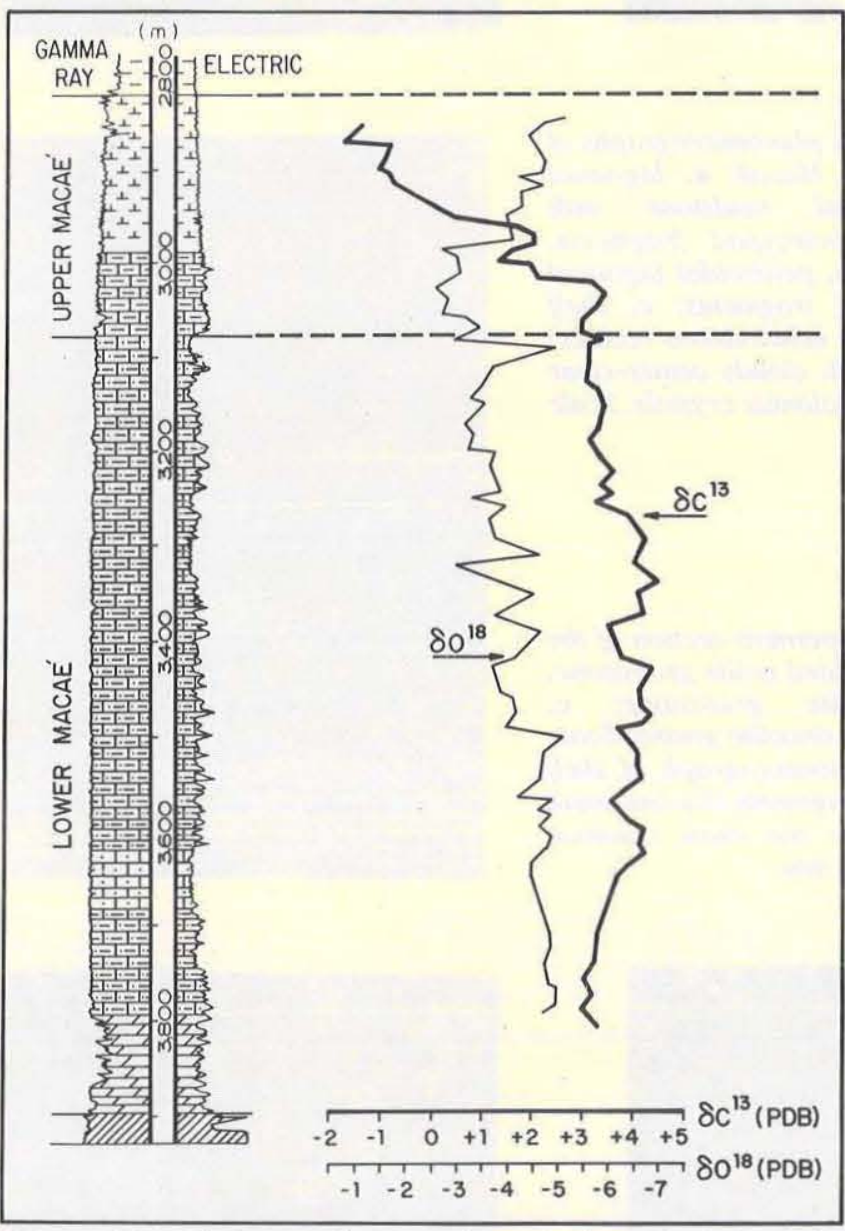

Figure 10 - Carbon and oxygen isotopic data of whole rocks samples. The data are given as per-mil deviation from $P D B$ standard

Pithonella ovalis, Bonetocardiella conoidea and other spheres not formally described until now (Dias-Brito 1982/5a). Planktonic foraminifera are mostly represented by Hedbergella and Ticinella species. The benthic foraminifera association is relatively important when compared with that of the Lower Macae, and are formed by Gyroidinoides aff. praestans, Globorotalites michelinianus, Osangularia utaturensis, Dorothia levis, D. oxycona, Clavulina gabonica, Lagena apiculata, Lenticulina spp., Gavelinella spp. Bolivina, Haplophragmoides, among others (Azevedo et al. 1987a).

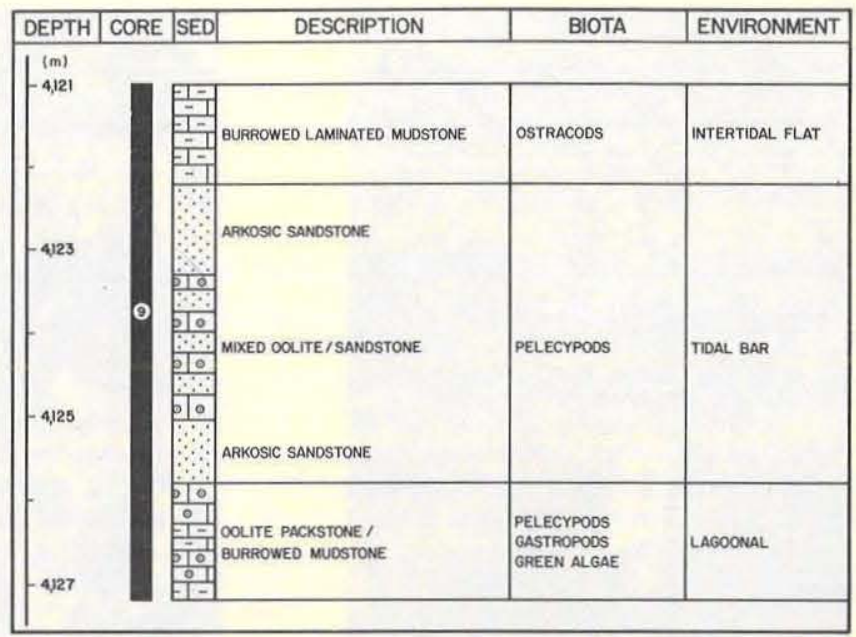

Figure 9 -Vertical sequence of mixed carhonate-siliciclastic facies in the lowermost portion of the Lower Macaé

Echinoderm fragments, pelecypods, and amonoids are rare.

The intermediate interval is formed by rhythmic carbonate mudstones and marls with basinwide distribution (Fig. 15), characterizing a chronostratigraphic marker (Spadini et al. 1987). The faunal content of this interval is similar to that of the basal section, but with aditional significative ammount of radiolarians. On the other hand, the carbonate matrix is here formed by a large ammount of coccoliths (calcite platelets of golden brown algae), characterizing a true chalk as defined by Scholle (1977).

The basal and intermediate interval facies were deposited in response to the progressive and accentuated sea level rise during the Late Albian, in accordance with the global eustatic curve (Haq et al. 1987). These limestones represents a typical pelagic sedimentation, as they are formed by coccoliths, which nowadays are responsible for generating significant ammounts of pelagic sediment (Mullins 1986). The paleoecological data, based on the association of benthic foraminifera, indicate that the deposition occurred in middle/deep neritic environment (Azevedo et al. op. cit.), with bathyal depths recognized in the northern portion of the basin (Fig. 16). The higher biotic diversity and frequence, comparing with that of Lower Macaé sequence, is attributed to the desalinization of the oceanic water, a process related to the expansion of the South Atlantic (Dias-Brito 1982, 1985a, $1985 \mathrm{~b}, 1987)$. The carbon isotope values are gradually less positive in this section (Fig. 16), pointing out to a better oceanic circulation, with the values approaching to those of normal marine limestones. The climate during the Late Albian was predominantly warm and dry, similar to that of the Lower Macaé, when the circulation pattern in the basin presented a negative water balance (Dias-Brito 1982). The calcilutite/marls rythms that characterizes the intermediate interval represent alternating warm/dry and warm/wet climatic cycles, preceding the drastic climatic change occurred post-albian times causing the termination of the cretaceous carbonate deposition in the Campos Basin. The connection between the North and South Atlantic that started in the Early to Middle Albian was in an advanced stage (Dias-Brito 1987). The occurrence of some species of radiolarians described by Kotzian \& Eilert (1987) suggests that the Macaé Sea was already connected even with the North Pacific and Central Pacific oceans.

The uppermost section of the Upper Macaé, Late Cenomanian to Early Turonian, is characterized by marls, with subordinate shales and sandstones turbidites. The marls are usually bioturbated (Planolites and rare Zoophycus). The faunal content of this section is totally different from those of the albian carbonates (Azevedo et al. 1987). The frequence and diversity of the biotic content along this interval is highly 


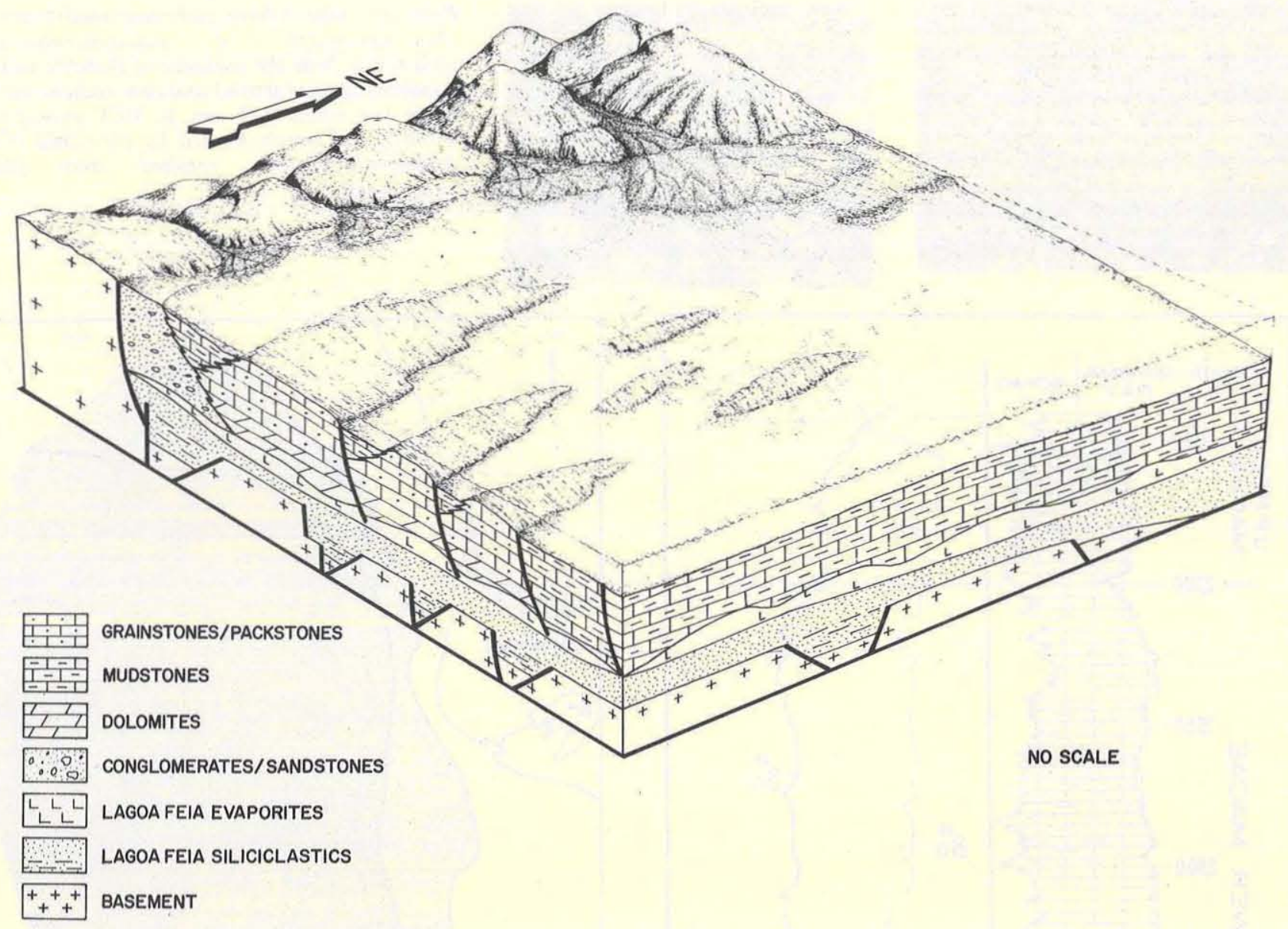

Figure II - Depositional model at the end of the Lower Macas (trom (iurdude \& Spadini 1987)

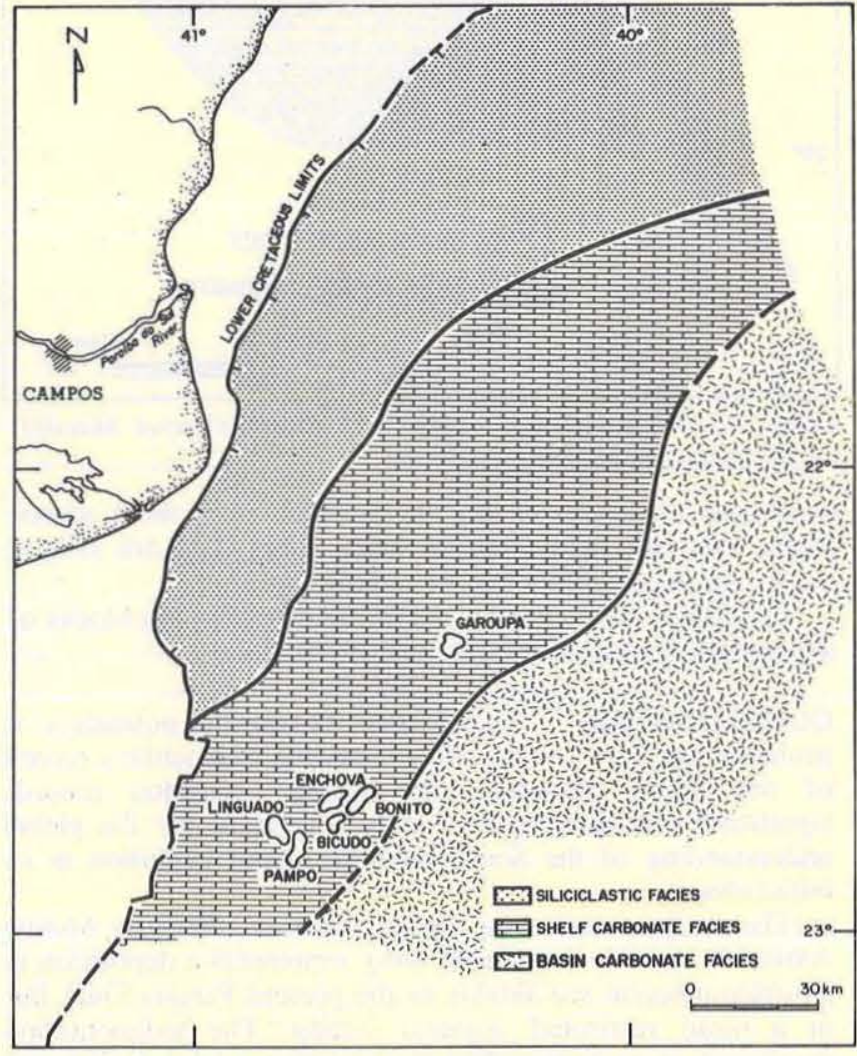

Figure 12 - Facies map at the end of the Lower Macaé (from Esteves et al. 1987)

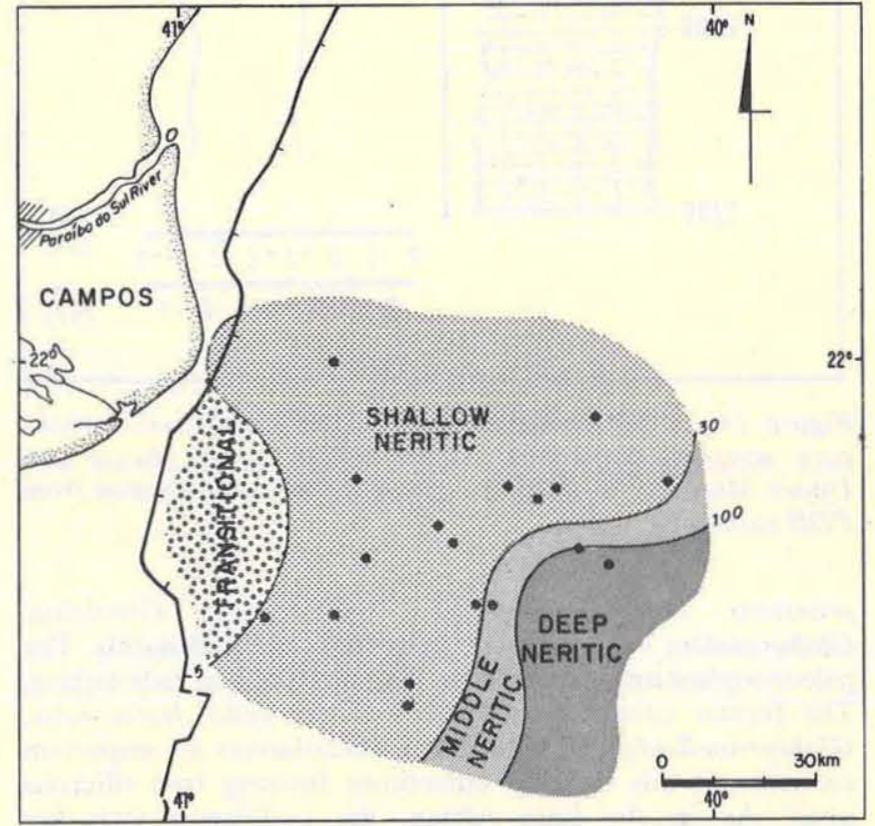

Figure 13 - Paleobathymetric map at the end of the Lower Macaé time (from Azevedo et al. 1987)

variated. Among the foraminifera, textularids are dominant; they include Haplophragmoides, Ammodiscus, Trochammina, Glomospira, Ammobaculites, Clavulina gabonica and Dorothia oxycona. The benthic calcareous foraminifera are represented by Lenticulina, Gavelinella, Gyroidinoic's aff. 

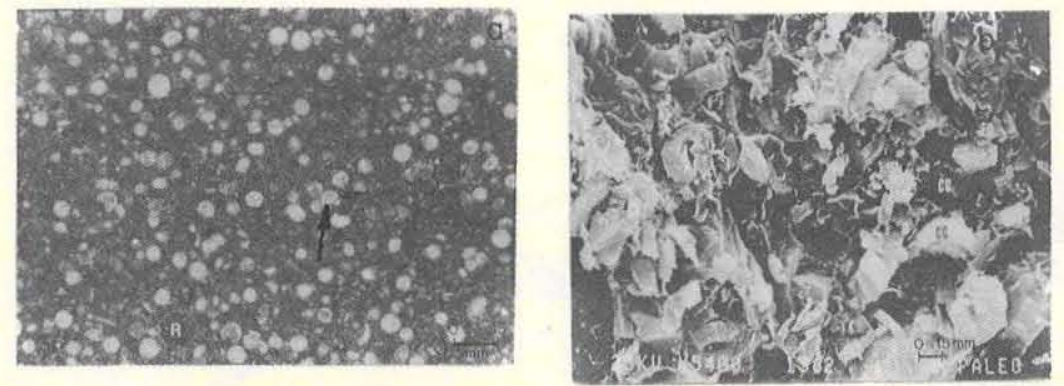

Plate 4 - Late Albian carbonate mudstones: a. photomicrograph of calcispherulids-rich mudstones. Note the presence of Bonetocardiella conoidea specie (arrow) and rare radiolaria ( $\mathrm{R})$. Scale bar equal $0.15 \mathrm{~mm}$; b. $M E V$ photograph showing the matrix formed by coccoliths (CC). Euhedral crystals resulted from plates overgrowth

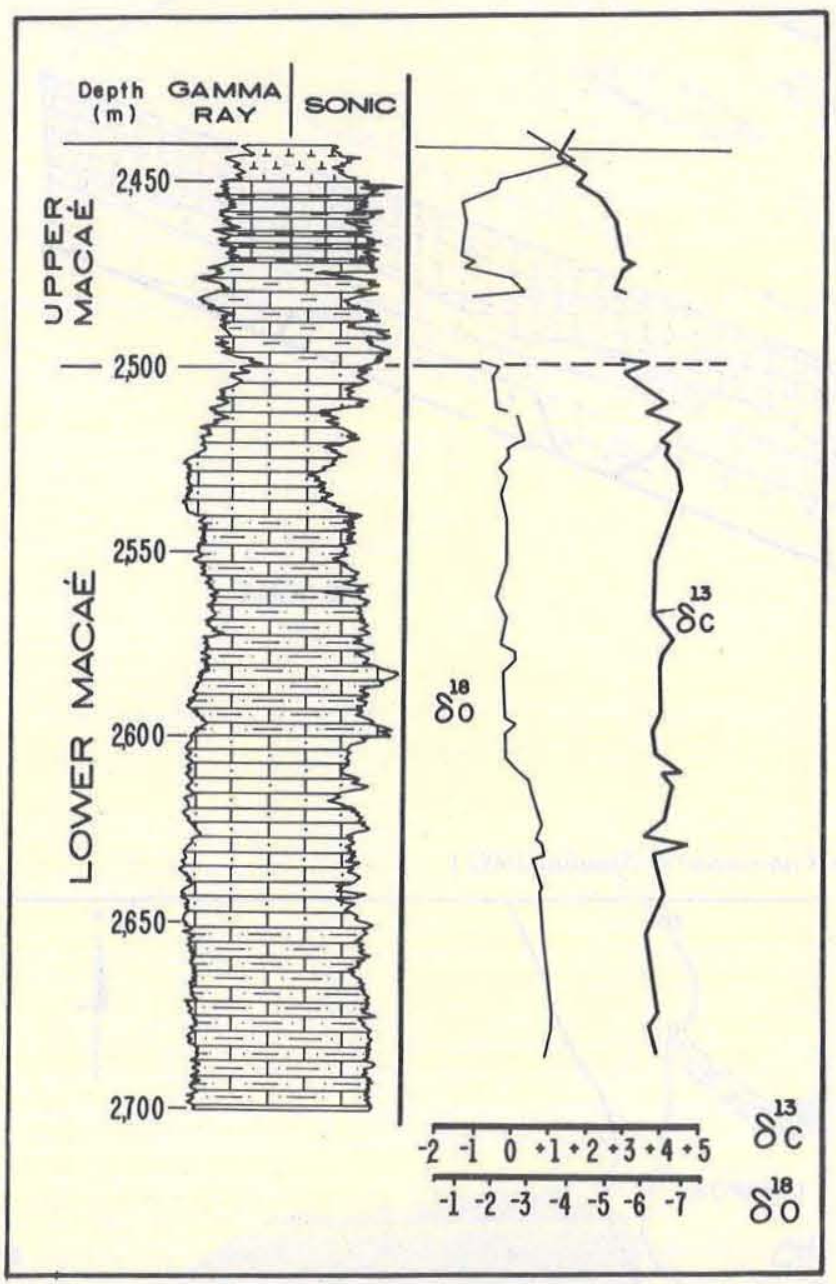

Figure 14 - Carbon and oxygen isotopic data of whole rocks core samples. Uppermost section of the Lower Macaé and Upper Macae. The data are given as per-mil deviation from $P D B$ standard

praestans, Lagena apiculata, Pleurostomella, Gyroidina, Globorotalites michelinianus, bolivinids, and nodosarids. The paleozooplankton is formed by foraminifera and radiolarians. The former comprise the genera Hedbergella, Heterohelix, Globigerinelloids, and Whiteinella. Radiolarians are important elements in this interval, sometimes forming true siliceous ooze. As in the Late Albian, the radiolarian tests are frequently calcitized.

This unit was deposited dominantly in a upper bathyal setting (Fig. 17), the basin presenting a positive water balance, where evaporation was less than precipitation and runoff. At this time, already under a warm/wet climate, episodic anoxic events are registered as indicated by the deposition of evenly laminated black shales. These shales sometimes show a monofauna of the foraminifera Neobulimina albertensis?, taxon similar to that one nowadays adapted to anoxic

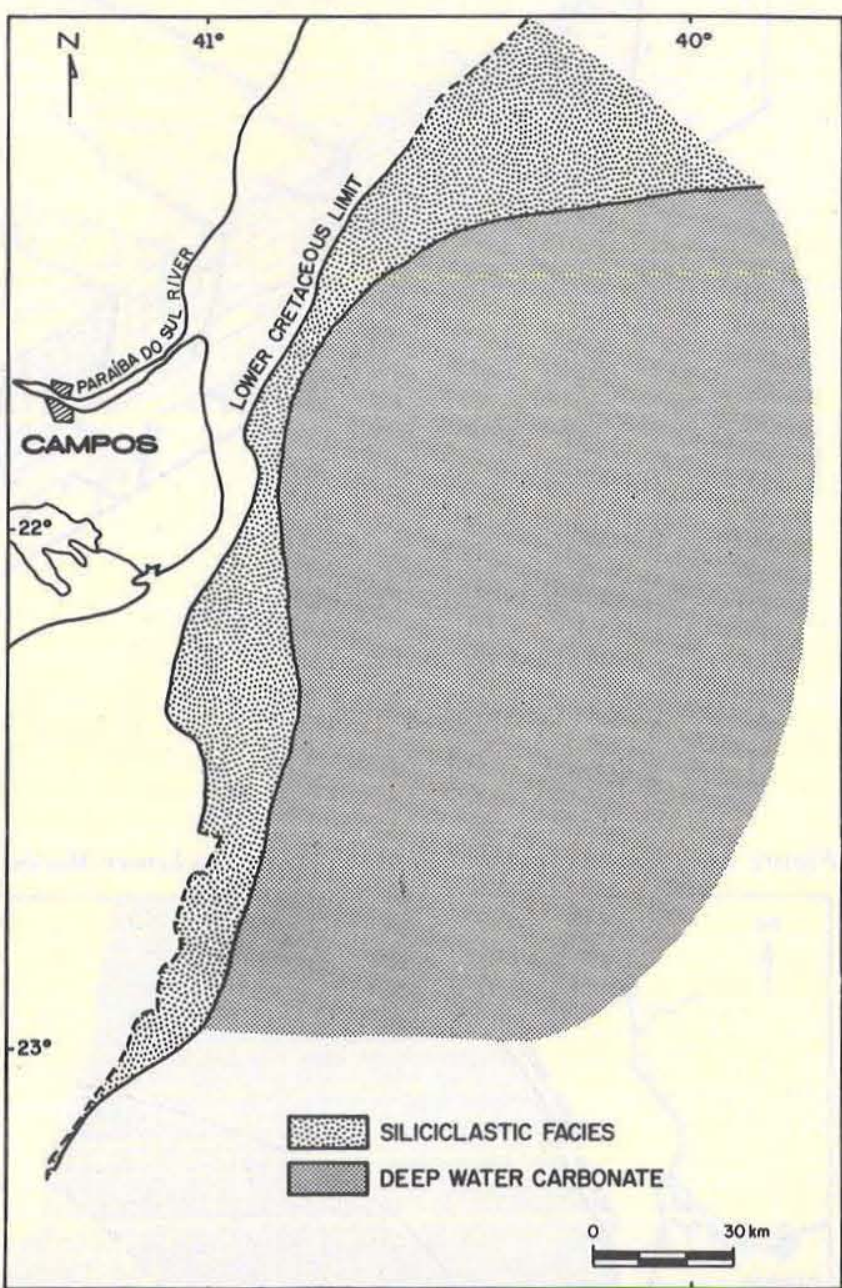

Figure 15 - Facies map of the Late Albian (Upper Macaé). From Spadini et al. 1987

conditions (Azevedo et al. 1987); other times these anoxic strata have no fauna, but in other cases they are rich in planktonic foraminifera and/or radiolarians.

Turbidites were channelized in the downthrown blocks of the growth faults (Guardado et al. 1986).

CONCLUSIONS The Macaé Formation nowadays is probably the best known mid-cretaceous sedimentary record of the South Atlantic. The Macaé deposition records significative oceanographic events, important for the global understanding of the South Atlantic Ocean evolution in its initial phases.

The shallow carbonate neritic sequence, Early to Middle Albian in age (Lower Macaé unit), represents a deposition in an epicontinental sea similar to the present Persian Gulf, but in a more restricted regional setting. The sedimentation developed in an hypersaline environment, under high water temperatures. The climate was at that time warm and dry. The base of this unit is formed mostly by peloidal/oolitic 


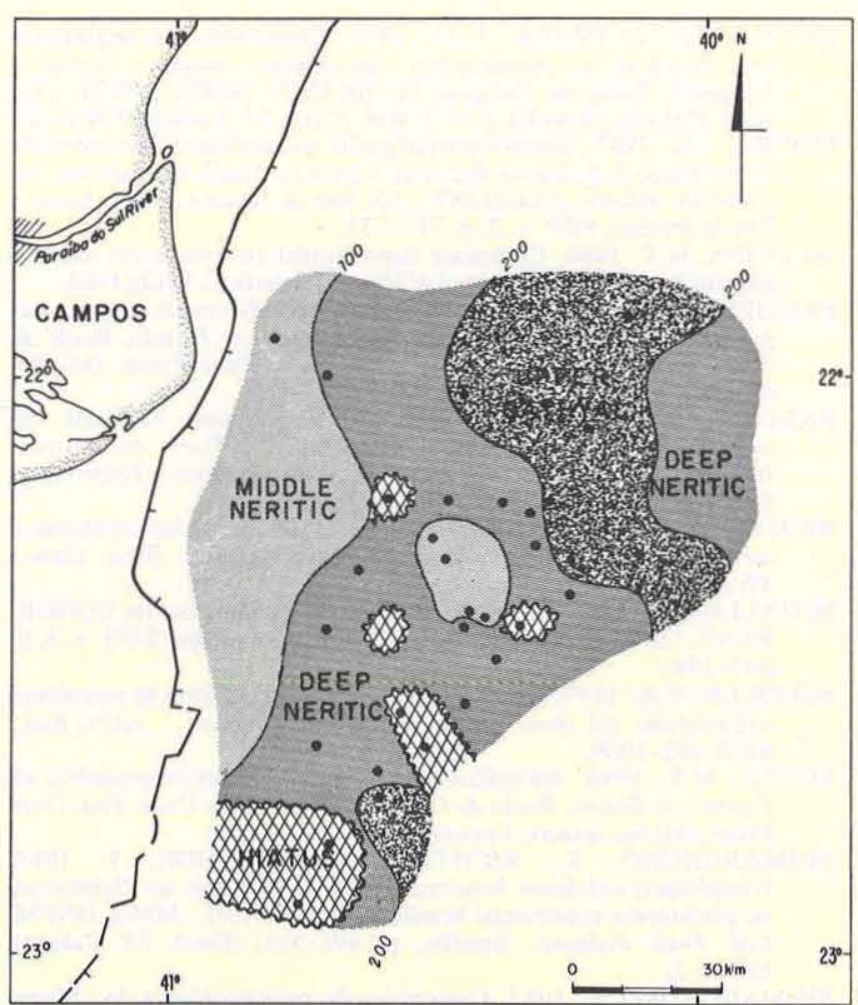

Figure 16 - Paleobathymetric map at the end of the Late Albian (from Azevedo et al. 1987)

packstones/grainstones, intensively dolomitized, whereas the middle and upper portions is formed mostly by oncolite-bearing limestones and mudstones. The biota content is characterized by the absence of typical bioelements known to be common in normal marine environments elsewhere at that time. A close relationship is established between subsidence/sea level rise and the carbonate production, contributing to mantain the shallow neritic conditions during the entire Lower Macaé time.

The Upper Macaé, comprising a carbonate sequence (Late Albian) and a predominantly marly section (Late Cenomanian to Early Turonian), records a progressive sea level rise. In the Late Albian, associated with the sea level change, the marine ecosystem became less saline due to a expressive increase in the water interchange with the North and South Atlantic oceans. The fine-grained limestones, with abundant ammounts of calcispherulids, accumulated mostly in a deep neritic environment, under warm/dry climatic conditions. At the end of the Late Albian mustone-marl rhythms were deposited as a response to warm/dry to warm/wet climatic cycles. These climatic alternances preceded the drastic climatic change that occurred in the Cenomanian which caused the termination of the Cretaceous carbonate

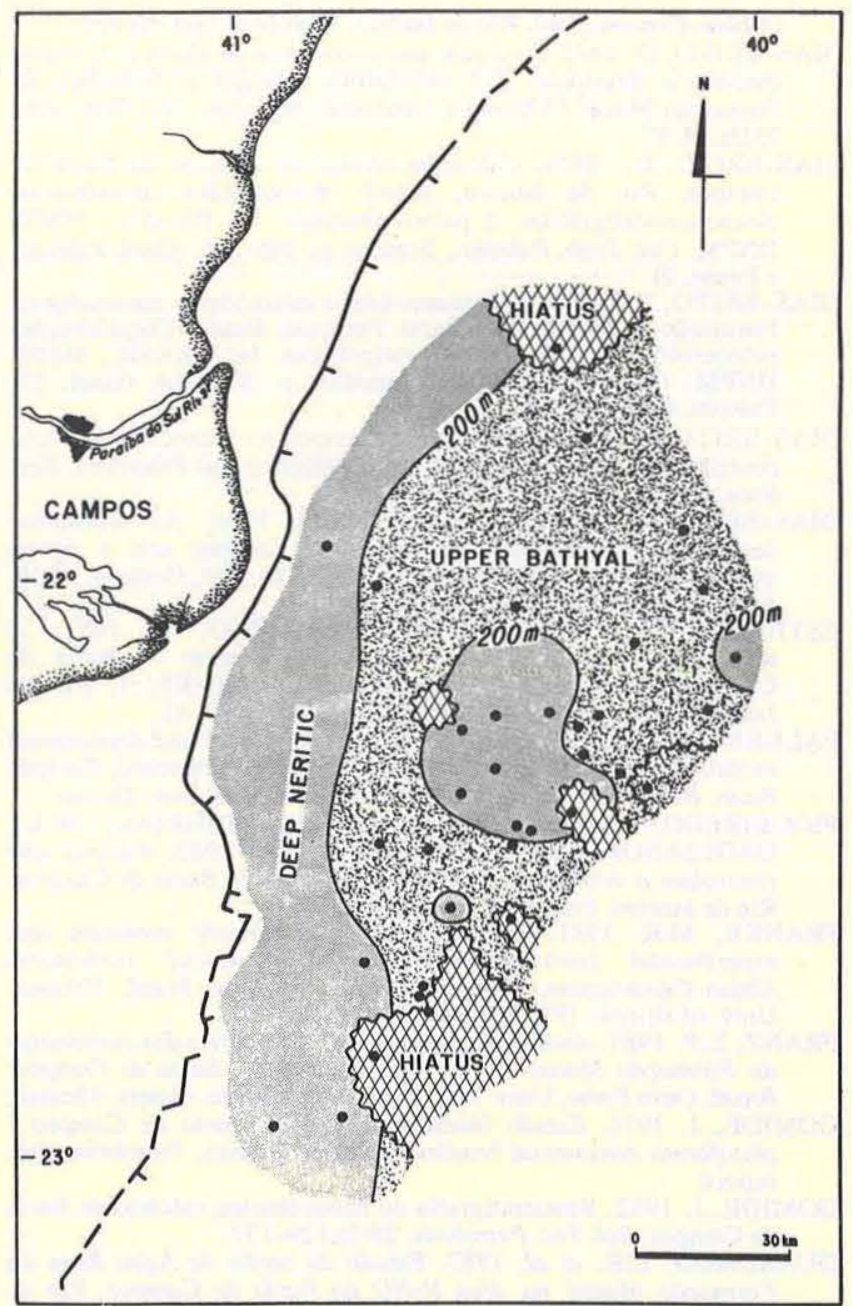

Figure 17 - Paleobathymetric map at the end of the Late Cenomanian/Lower Turonian (from Azevedo et al. 1987)

sedimentation in the Campos Basin.

The Late Cenomanian to Early Turonian deposits were accumulated in 200-300 m water depth. Opposing the preceding phases, when the system presented a negative water balance, the basin was submitted to a positive water balance. The climate was then warm and wet. Despite the advanced stage of the continental drifting, no fully normal marine conditions was reached at the time, as evidenced by the presence of black shales layers, accumulated in episodic anoxic events. Oceanic conditions are only recorded in the sediments overlying the Macaé deposits.

Acknowledgements The authors wish to thank to Petrobrás for permission to publish this paper. They are also grateful to all colleagues that contributed for this work.

\section{REFERENCES}

ANTUNES, R.L.; SONOKI, N.T.; CARMINATTI, M. 1988. The Enchova Paleocanyon (Campos-Brasil): its Oligocene-Miocene history based on calcareous nannoplankton stratigraphy and seismostratigraphy, Rev, Bras, Geoc., 18(3):291-298

ASMUS, H.E. 1975. Controle estrutural da deposição mesozóica nas bacias da margem continental brasileira. Rev. Bras. Geoc., 5(3): $160-165$.

ASMUS, H.E. \& PORTO, R. 1980: A diferença dos estágios iniciais da evolução da margem continental brasileira: possíveis causas e implicações. In: CONGR. BRAS GEOL. 31, Baln. Camboriú, 1980. Anais. Baln. Camboriú, SBG. v. 1, p. 225-239.

AZEVEDO, R.L.M.; GOMIDE, J.; VIVIERS, M.C.; HASHIMOTO, A.T. 1987a. Bioestratigrafia do Cretáceo marinho da Bacia de Campos, Brasil. Rev. Bras. Geoc., 17(2):147-153.

AZEVEDO, R.L.M.; GOMIDE, J.; VIVIERS, M.C. 1987b. Geo-história da Bacia de Campos, Brasil: do Albiano ao Maastrichtiano. Rev. Bras. Geoc., 17(2):139-146.
BAUMGARTEN, C.S. et al. 1982. Projeto Garoupa. Rio de Janeiro, Petrobrás. (Int. report)

BAUMGARTEN, C.S. et al. 1984. Projeto Bonito. Rio de Janeiro, Petrobrás. (Int. report)

BELTRAMI, C.V. 1982. Mapa paleogeográfico de progresso da Formação Macaé Inferior. Rio de Janeiro, Petrobrás. (Int. report)

BOLLI, H.M. 1978. Cretaceous and Paleogene calcisphaerulidae from DSDP Leg 40, southeastern Atlantic, In: BOLLI, H.M.\& RYAN, W.E.F., Initial reports of the Deep Sea Drilling Project. Washington, U.S. Gov. Print. Office. 40:819-837.

BUDD, D.A. \& LOUCKS, R.G. 1981. Smackover and Lower Buckner Formations, South Texas: depositional systems on a Jurassic Carbonate Ramp. Bureau of Economic Geology. The University of Texas at Austin. 120p. (Rep. Invest. 112)

CAROZZI, A.V.; FALKENHEIN, U.F.H.; LUCCHESI, C.F., MÉRCIO, R.; ANSALONI, B. 1977. Microfacies and depositional-diagenetic evolution of Macaé Carbonates 
(Albian-Cenomanian), Rio de Janeiro, Petrobrás, (Int, report)

DIAS-BRITO, D. 1982. Evolução paleoecológica da Bacia de Campos durante a deposiçāo dos calcilutitos, margas e folhelhos da Formação Macaé (Albiano e Cenomaniano). Bol. Téc. Petrobrás, 25(2):84-97.

DIAS-BRITO, D. 1985a. Calcisphaerulidae do Albiano da Bacia de Campos, Rio de Janeiro, Brasil: investigações taxonômicas, biocronoestratigráficas e paleoambientais. In: BRASIL, MME, DNPM. Col. Trab. Paleont., Brasília. p. 295-305. (Geol. Paleont. e Estrat. 2)

DIAS-BRITO, D. 1985b. Calisphaerulidae e microfósseis associados da Formação Ponta do Mel-Bacia Potiguar, Brasil: Consideraçōes paleoecológicas e biocronoestratigráficas. In: BRASIL, MME, DNPM. Col. Trab. Paleont., Brasília. p. 307-314. (Geol. 27, Paleont. Estrat. 2)

DIAS-BRITO, D. 1987. A Bacia de Campos no Mesocretáceo: uma contribuição à paleoceanografia do Atlântico Sul Primitivo. Rev. Bras. Geoc., 17(2):162-167.

DIAS-BRITO, D. \& AZEVEDO, R.L.M. 1986. As seqüências deposicionais marinhas da Bacia de Campos sob a óptica paleoecológica. In:CONGR. BRAS. GEOL., 34, Goiânia, 1986. Anais... Goiânia, SBG. v. 1, p. 38-49.

ESTEVES, F.R.; SPADINI, A.R.; MAKOTO, S. 1987. A sedimentação albo-turoniana (Formação Macaé) da Bacia de Campos. In: SIMP. GEOL. REGIONAL RJ-ES, 1, Rio de Janeiro, 1987. Anais... Rio de Janeiro, SBG. p. 27-42.

FALKENHEIN, U.F.H. 1981. Carbonate microfacies and depositional evolution of the Macaé Formation (Albian-Cenomanian), Campos Basin, Brazil. Urbana, Univ. of Illinois. (Ph. D. dissert. Thesis)

FIGUEIREDO, A.M.F; PEREIRA, M.J.; MOHRIAK, W.U.; GAGLIANONE, P.C.; TRINDADE, L.A. 1983. Fatores que controlam a ocorrência de hidrocarbonetos na Bacia de Campos. Rio de Janeiro. Petrobrás. (Int. report)

FRANKE, M.R. 1981. Natural porosity, diagenetic evolution and experimental porosity development of Macaé carbonates Albian-Cenomanian, Campos Basin, Offshore Brazil. Urbana, Albian-Cenomanian, Campos Basin,
Univ. of Illinois. (Ph. D. dissert. Thesis)

FRANZ, E.P. 1987. Análise da geologia de reservatório dos carbonatos da Formação Macaé do Campo de Enchova-Bacia de Campos, Brasil. Ouro Preto, Univ. Fed, Ouro Preto. (M.Sc. dissert. Thesis)

GOMIDE, J. 1976. Estudo bioestratigráfico da Bacia de Campos plataforma continental brasileira. Rio de Janeiro, Petrobrás. (Int. report)

GOMIDE, J. 1982. Bioestratigrafia do nanoplânctọn calcário da Bacia de Campos, Bol. Téc. Petrobrás, 25(3):129-137.

GUARDADO, L.R et al. 1983. Estudo da seção de Água Rasa da Formaçẫo Macaé na área N-NO da Bacia de Campos. Rio de Janeiro, Petrobrás. (Int. report)

GUARDADO, L.R.; PERES, W.E.; CRUZ, C.E.S. 1986. Depositional model and seismic expression of turbidites in Campos Basin, offshore Brazil. AAPG Bull., 70(5):597.

GUARDADO, L.R. \& SPADINI, A.R. 1987. Evolução deposicional e distribuição das fácies de Macaé Inferior (Eomesoalbiano, Bacia de Campos). B. Geoc. Petrobrás, 1(2):237-239.

HAQ, B.U.; HARDENBOL, J.; VAIL, P.R. 1987. Chronology of Fluctuating sea level since the Triassic. Science, 235:1156-1166.

HULTEBERG, S.U. 1985. Pithonella organica - a new calcareous dinoflagellate with an inner organic wall. Grana, 24:115-120.

KEUPP, H. 1987. Die kalkigen Dinoflagellatenzysten des Mittelalb bis Untercenoman von Escalles/Boulonnais (N-Frankreich). Facies, 16:37-88.

KOTZIAN, S.C.B. \& EILERT, V.B. 1987. Radiolários do Cretáceo "Médio" na Bacia de Campos, Brasil. In: CONGR. BRAS. PALEONT., 10, Rio de Janeiro, 1987. Anais... Rio de Janeiro, SBP. v. 2, p. 783-796.

KOUTSOUKOS, E.A.M. 1984. Evolução paleoecológica do Albiano ao Maastrichtiano na área noroeste da Bacia de Campos, Brasil, com base em foraminíferos. In: CONGR. BRAS. GEOL., 33, Rio de Janeiro, 1984. Anais... Rio de Janeiro, SBG. v. 3, p. 685-698.

KOUTSOUKOS, E.A.M. 1987. A área noroeste da Bacia de Campos, Brasil, do Mesocretáceo ao Neocretáceo: evoluçảo paleoambiental e paleogeográfica pelo estudo de foramíniferos. Rev. Bras. Geoc., 17(2):168-172.

LEONARD, J.E.; CAMERON, B.; PILKEY, O.H.; FRIEDMAN, G.M. 1981. Evaluation of, cold-water carbonates as a possible paleoclimate indicator. Sed. Geol., 28:1-28.

LOREAU, J.P. \& PURSER, B.H. 1973. Distribution and ultrastructure of Holocene ooids in the Persian Gulf. In: PURSER, B.H. ed. The Persian Gulf. New York, Springer-Verläg, p. 279-328.
MOURA, J.A. \& PRAÇA, U.M. 1985. Ostracodes das seqüências nảo-marinhas e transicionais mesozóicas (andares Jiquiá e Alagoas), Bacia de Campos. In: BRASIL, MME, DNPM, Col. Trab. Paleont., Brasília. p. 401-408. (Geol. 27, Paleont. Estrat. 2)

MOURA, J.A. 1987. Biocronoestratigrafia da seqüencia nāo-marinha do Cretáceo Inferior da Bacia de Campos, Brasil: Ostracodes. In: CONGR. BRAS. PALEONT., 10, Rio de Janeiro, 1987. Anais... Rio de Janeiro, SBP. v. 2, p. 717-731.

MULLINS, H.T. 1986. Carbonate depositional environments modern and ancient. Colorado School of Mines Quaterly J., 81(2):1-63.

PAUMER, M.L. 1984. Microfácies, evolução diagenética e o meio poroso dos reservatórios Macaé no Campo de Bicudo, Bacia de Campos, Brasil. Ouro Preto, Univ. Fed. Ouro Preto. (M. Sc. dissert. Thesis)

RICHTER, A.J. 1985. Aplicação de nanofósseis calcários no mapeamento da discordância pré-eocênica na Bacia de Campos. In: BRASIL, MME, DNPM. Col. Trab. Paleont., Brasília. p. 471-480. (Geol. 27 Paleont. Estrat. 2)

RICHTER, A.J. 1987. Subafloramento das discordâncias turoniana e campaniana no sul da Bacia de Campos. Rev. Bras. Geoc., 17(2):173-176

SCHALLER, H. 1973. Estratigrafia da Bacia de Campos. In: CONGR. BRAS. GEOL., 27, Aracaju, 1973. Anais... Aracaju, SBG. v. 3, p. 247-258.

SCHOLLE, P.A. 1977. Chalk diagenesis and its relation to petroleum exploration: oil from chalks, a modern miracle? AAPG Bull., 61(7):982-1009.

SCUTA, M.S. 1984. Microfácies, diagênese e fácies-reservatório do Campo de Bonito, Bacia de Campos. Ouro Preto. Univ. Fed. Ouro Preto. (M. Sc. dissert. Thesis)

SHIMABUKURO, S.; RICHTER, A.J.; GOMIDE, J. 1985 Nanofósseis calcários: bioestratigrafia do Mioceno ao Pleistoceno na plataforma continental brasileira. In: BRASIL, MME, DNPM. Col. Trab. Paleont., Brasília. p. 491-501. (Geol. 27, Paleont. Estrat. 2)

SHIMABUKURO, S. 1987. Caracterização paleobiológica do "Marco Azul": um importante marco estratigráfico oligocênico na Bacia de Campos, Brasil. In: CONGR. BRAS. PALEONT., 10, Rio de Janeiro, 1987. Anais... Rio de Janeiro, SBP. v. 2, p. 1043-1053.

SHINN, E.A. 1983. Tidal flat environment. In: SCHOLLE, P.A.et al. ed. Carbonate depositional environment. Tulsa, p. 171-210. (AAPG Memoir 33)

SPADINI, A.R. 1982. Calcários de granulação fina da Formação Macaé, Bacia de Campos. In: CONGR. BRAS. PETRÓLEO, 2, Rio de janeiro, 1982. Anais... Rio de Janeiro, IBP. (Trab. n 18)

SPADINI, A.R. \& PAUMER, M.L. 1983. Os reservatórios Macaé no Campo de pampo: o meio poroso e a diagênese. Rio de Janeiro, Petrobrás. (Int. report)

SPADINI, A.R. \& FARIA, R.T. 1986. Ó́litos: sua ocorrência na seqüência carbonática albiana da Bacia de Campos e seu interesse como rocha-reservatório. In: CONGR. BRAS. GEOL., 34, Goiânia, 1986. Anais... Goiânia, SBG. v. 4, p. 1689-1700.

SPADINI, A.R.; ESTEVES, F.R.; AZEVEDO, R.L.M. 1987. O ritmito do Albiano Superior da Formaçāo Macaé, Bacia de Campos: um marco estratigráfico com significado paleoambiental e cronoestratigráfico. In: CONGR. BRAS. PALEONT., 10, Rio de Janeiro, 1987. Anais... Rio de Janeiro, SBP. v. 2, p. 1027-1041.

TAKAKI, T. \& RODRIGUES, R. 1984. Isótopos estáveis do carbono e oxigênio dos calcários como indicadores paleoambientais, Bacia de Campos, Santos e Espírito Santo. In: CONGR. BRAS GEOL., 33, Rio de Janeiro, 1984. Anais... Rio de Janeiro, SBG. v. 3 , p. 4750-4762.

TESSARI, E. \& TIBANA, P. 1975. Interpretaçäo preliminar da evolução sedimentológica da Formação Macaé. Rio de Janeiro, Petrobrás (Int. report)

UESUGUI, N. 1976. Intervalos bioestratigráficos da Bacia de Campos do Albiano ao Santoniano, Rio de Janeiro, Petrobrás. (Int. report)

VIVIERS, M.C. \& AZEVEDO, R.L.M. 1988. The southeastern area of the Brazilian Continental Margin: the evolution during the Middle and Late Cretaceous as indicated by paleoecological data. Rev. Bras. Geoc. 18(3):(no prelo)

WILSON, J.L. 1975. Carbonate facies in geologic history. Springer-Verlag, $471 \mathrm{p}$. 